\title{
Low-Altitude Photographic Transects of the Arctic Network of National Park Units and Selawik National Wildlife Refuge, Alaska, July 2013
}

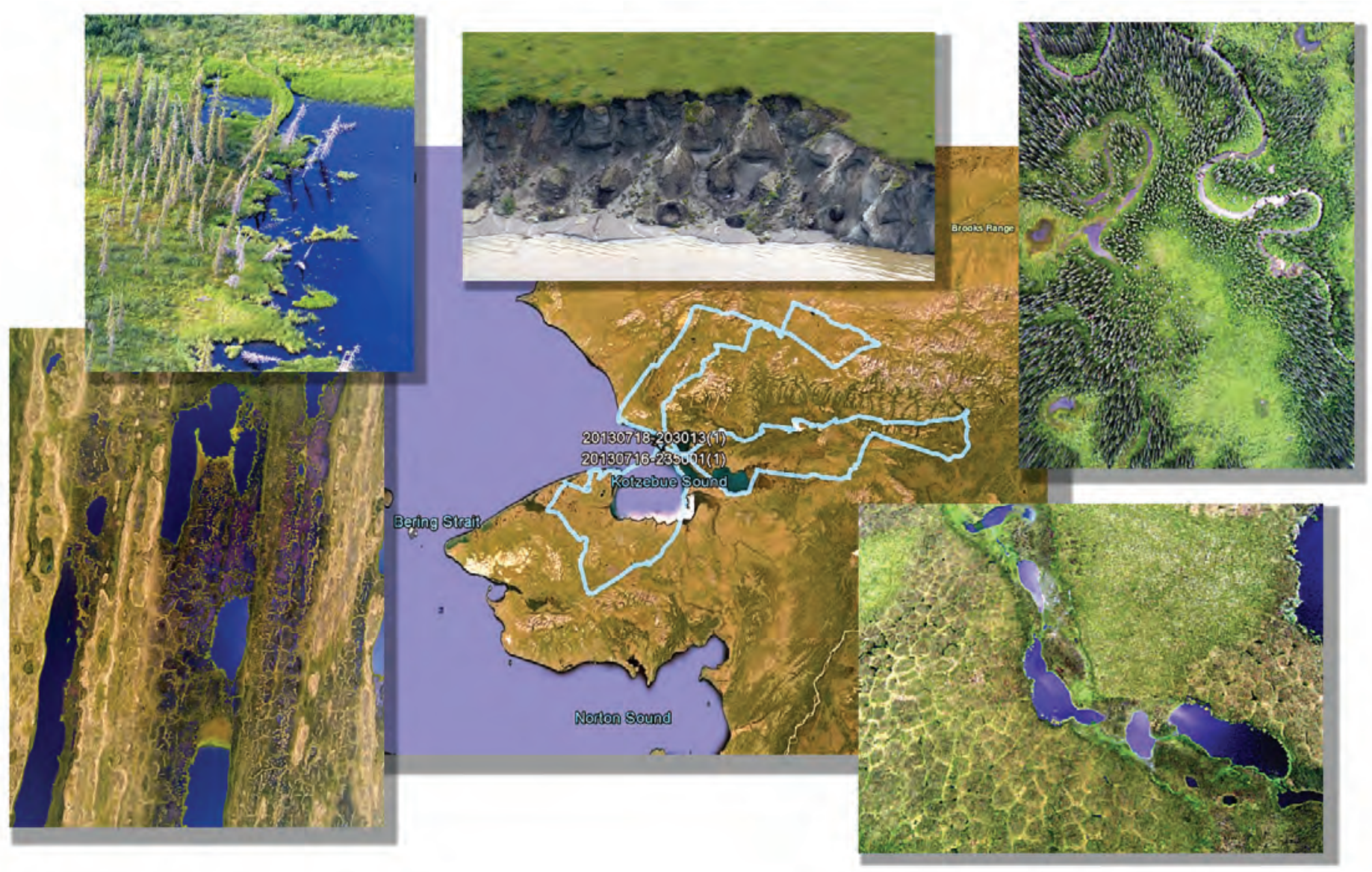

Data Series 846 
Cover:

Center: transect flight paths in northwest Alaska (Google Earth ${ }^{\circledR}$ map).

Photographs from transect series, clockwise from lower left: coastal water and lowland circumacidic sedge fen, Cape Espenberg, Bering Land Bridge National Preserve (photograph ARCN 130716 Bering, GoPro 0117_pt.jpg); white spruce "drunken trees" and soil subsidence from permafrost melt by tundra lake, Selawik National Wildlife Refuge (photograph ARCN 130717 KobGatSel, Lumix 1116.jpg); coastal erosion, Baldwin Peninsula (photograph ARCN 130717

KobGatSel, Lumix 1331.jpg); riverine white spruce-willow forest and riverine loamy moist alder or willow tall shrub, Noatak National Preserve (photograph ARCN 130718 NoaKru, Drift 2997 pt.jpg); upland organic-rich moist acidic dwarf birch-tussock shrub, Noatak National Preserve (photograph ARCN 130718 NoaKru, Drift 0890_pt.jpg). 


\section{Low-Altitude Photographic Transects of the Arctic Network of National Park Units and Selawik National Wildlife Refuge, Alaska, July 2013}

By Bruce G. Marcot, M. Torre Jorgenson, and Anthony R. DeGange

Data Series 846 


\title{
U.S. Department of the Interior SALLY JEWELL, Secretary
}

\section{U.S. Geological Survey \\ Suzette M. Kimball, Acting Director}

\author{
U.S. Geological Survey, Reston, Virginia: 2014
}

For more information on the USGS - the Federal source for science about the Earth, its natural and living resources, natural hazards, and the environment, visit http://www.usgs.gov or call 1-888-ASK-USGS.

For an overview of USGS information products, including maps, imagery, and publications, visit http://www.usgs.gov/pubprod

To order this and other USGS information products, visit http://store.usgs.gov

Any use of trade, firm, or product names is for descriptive purposes only and does not imply endorsement by the U.S. Government.

Although this information product, for the most part, is in the public domain, it also may contain copyrighted materials as noted in the text. Permission to reproduce copyrighted items must be secured from the copyright owner.

Suggested citation:

Marcot, B.G., Jorgensen, M.T., and DeGange, A.R., 2014, Low-altitude photographic transects of the Arctic Network of National Park Units and Selawik National Wildlife Refuge, Alaska, July 2013: U.S. Geological Survey Data Series 846, 44 p., http://dx.doi.org/10.3133/ds846.

ISSN 2327-638X (online) 


\section{Contents}

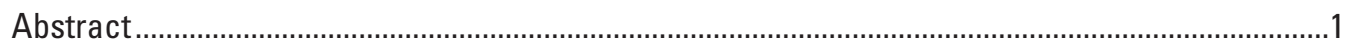

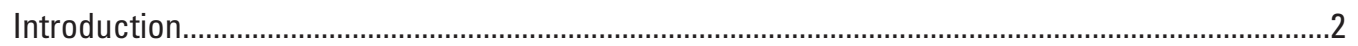

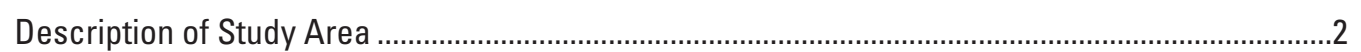

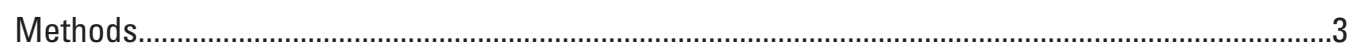

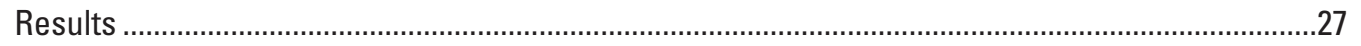

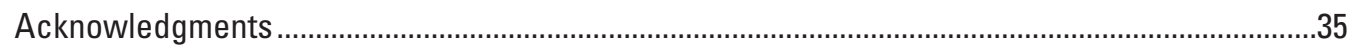

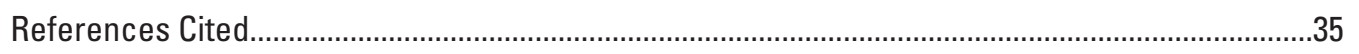

Appendix 1. Calculations of Time-Lapse Interval Needed for Continuous Flight Line

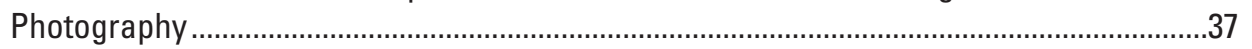

Appendix 2. Details of Photograph Processing ………..........................................................39

Appendix 3. Analysis of Ecotype Coverage in Photographs.......................................................42

Appendix 4. Metadata Documentation of Arctic Network Photograph Database Files.................43

\section{Figures}

1. Map showing study area in northwest Alaska comprising five national park units and one national wildlife refuge (NWR) and a surrounding $10-\mathrm{km}$ buffer 2

2. Image showing flight path with altitude and speed profiles on July 16, 2013, over Bering Land Bridge National Preserve, northwest Alaska.

3. Image showing flight path, with altitude and speed profiles on July 17, 2013, over Kobuk Valley National Park, Gates of the Arctic National Park and Preserve, and Selawik National Wildlife Refuge, northwest Alaska.

4. Image showing flight transect route with altitude and speed profiles on July 18, 2013, over Noatak National Preserve and Cape Krusenstern National Monument, northwest Alaska.

5. Photographs showing locations of external cameras secured to the airplanes for low-level aerial photography...............................................................................................

6. Image showing photographic coverage for July 16, 2013, of Bering Land Bridge National Preserve, northwest Alaska...

7. Image showing photographic coverage on July 17, 2013, of Kobuk Valley National Park, Gates of the Arctic National Park and Preserve, and Selawik National Wildlife Refuge, northwest Alaska

8. Image showing photographic coverage, on July 18, 2013, of Noatak National Preserve and Cape Krusenstern National Monument, northwest Alaska...

9. Photographs showing example of photographic enhancement and correction for lens distortion, of one photograph taken by GoPro ${ }^{\circledR}$ Hero3 camera in northeast coastal section of Bering Land Bridge National Preserve, northwest Alaska, on July 16, 2013.

10. Examples of photographs taken with the GoPro ${ }^{\circledR}$ Hero3 Black Edition camera in the transect series, northwest Alaska

11. Examples of photographs of disturbance and dynamic processes available in the transect series, northwest Alaska.. 


\section{Figures-Continued}

12. Examples of panoramic images stitched from multiple, adjacent photographs along the photographic transect routes

13. Example of an individual frame-capture from one of the continuous GoPro ${ }^{\circledR}$ Hero3 camera video segments, northwestern Alaska

14. Graph showing ecotypes represented in all photographs in each of the Arctic Network flight transect routes on July 16-18, 2013.

15. Example of color- and gamma-adjusted and lens distortion-corrected GoPro ${ }^{\circledR}$ photograph compared with IKONOS and Worldview images.

\section{Tables}

1. Hardware used for global positioning system (GPS) and photography

2. Number of global positioning system (GPS) waypoints, number of photographs, and flight time and distance.

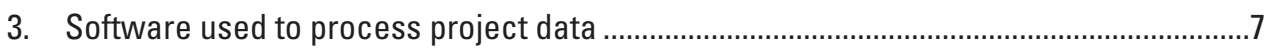

4. Naming convention of photographs and their computer subdirectories........................25

5. Video files of land cover from GoPro ${ }^{\circledR}$ Hero3 camera ......................................................33

6. Average and standard deviation (SD) of flight altitude of geotagged nadir photographs taken with the Drift ${ }^{\circledR}$ HD-170 and GoPro® Hero3 Black Edition cameras 
Conversion Factors, Datums, and Acronyms and Abbreviations

\section{Conversion Factors}

Inch/Pound to SI

\begin{tabular}{|c|c|c|}
\hline Multiply & By & To obtain \\
\hline \multicolumn{3}{|c|}{ Length } \\
\hline foot (ft) & 0.3048 & meter (m) \\
\hline
\end{tabular}

SI to Inch/Pound

\begin{tabular}{lll}
\hline \multicolumn{1}{c}{ Multiply } & By & \multicolumn{1}{c}{ To obtain } \\
\hline millimeter (mm) & Length & \\
meter (m) & 0.03937 & inch (in.) \\
kilometer (km) & 3.281 & foot (ft) \\
meter (m) & 0.6214 & mile (mi) \\
\hline hectare (ha) & 1.094 & \\
hectare (ha) & Area & acre \\
\hline
\end{tabular}

\section{Datums}

Vertical coordinate information is referenced to the North American Vertical Datum of 1988 (NAVD 88).

Horizontal coordinate information is referenced to the North American Datum of 1983 (NAD 83).

Altitude, as used in this report, refers to distance above the vertical datum. 


\section{Conversion Factors, Datums, and Acronyms and Abbreviations}

\section{Acronyms and Abbreviations}

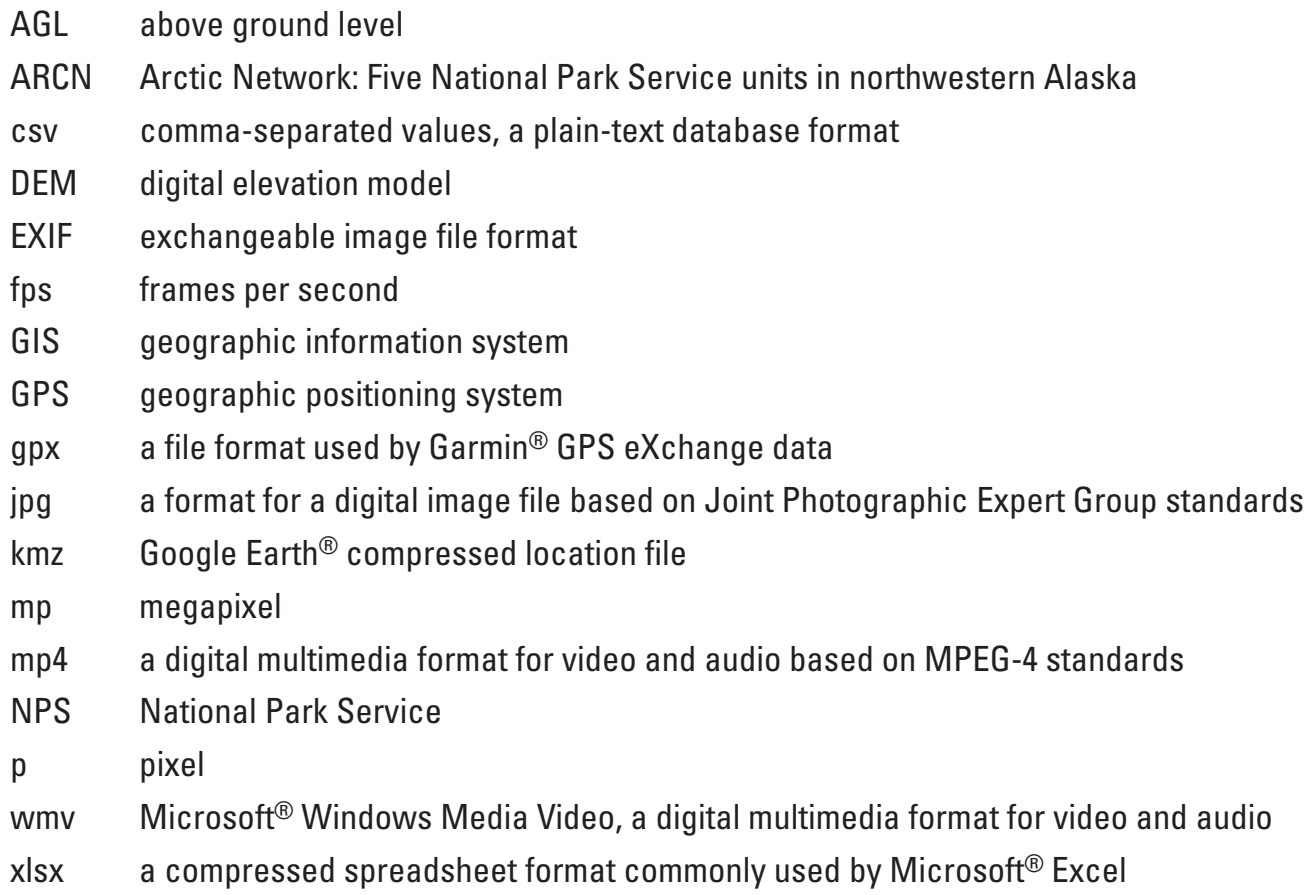




\title{
Low-Altitude Photographic Transects of the Arctic Network of National Park Units and Selawik National Wildlife Refuge, Alaska, July 2013
}

\author{
By Bruce G. Marcot' ${ }^{1}$ M. Torre Jorgenson ${ }^{2}$, and Anthony R. DeGange ${ }^{3}$
}

\begin{abstract}
During July 16-18, 2013, low-level photography flights were conducted (with a Cessna 185 with floats and a Cessna 206 with tundra tires) over the five administrative units of the National Park Service Arctic Network (Bering Land Bridge National Preserve, Cape Krusenstern National Monument, Gates of the Arctic National Park and Preserve, Kobuk Valley National Park, and Noatak National Preserve) and the U.S. Fish and Wildlife Service's Selawik National Wildlife Refuge in northwest Alaska, to provide images of current conditions and prevalence of land-cover types as a baseline for measuring future change, and to complement the existing grid-based sample photography of the region. Total flight time was 17 hours, 46 minutes, and total flight distance was 2,590 kilometers, at a mean altitude of about 300 meters above ground level.
\end{abstract}

A total of 19,167 photographs were taken from five digital camera systems:

1. A Drift ${ }^{\circledR} \mathrm{HD}-170$ (focal length $5.00 \mathrm{~mm}$ );

2. $\quad$ A GoPro ${ }^{\circledR}$ Hero3 Black Edition (focal length $2.77 \mathrm{~mm}$ );

3. A Panasonic ${ }^{\circledR}$ Lumix DMC-FZ200 (24× superzoom with variable focal length);

4. A Panasonic ${ }^{\circledR}$ Lumix DMC-SZ7 (10× superzoom with variable focal length); and

5. A Canon ${ }^{\circledR}$ Rebel 3Ti with a Sigma zoom lens (18-200 mm focal length).
The Drift ${ }^{\circledR}$ HD-170 and GoPro ${ }^{\circledR}$ Hero3 cameras were secured to the struts and underwing for nadir (direct downward) imaging. The Panasonic ${ }^{\circledR}$ and Canon ${ }^{\circledR}$ cameras were each hand-held for oblique-angle landscape images, shooting through the airplanes' windows, targeting both general landscape conditions as well as landscape features of special interest, such as tundra fire scars and landslips.

The Drift ${ }^{\circledR}$ and GoPro ${ }^{\circledR}$ cameras each were set for time-lapse photography at 5-second intervals for overlapping coverage. Photographs from all cameras (100 percent .jpg format) were date- and time-synchronized to geographic positioning system waypoints taken during the flights, also at 5-second intervals, providing precise geotagging (latitudelongitude) of all files. All photographs were adjusted for color saturation and gamma, and nadir photographs were corrected for lens distortion for the Drift ${ }^{\circledR}$ and GoPro ${ }^{\circledR}$ cameras' $^{\prime} 170^{\circ}$ wide-angle distortion. EXIF (exchangeable image file format) data on camera settings and geotagging were extracted into spreadsheet databases. An additional 1 hour, 20 minutes, and 43 seconds of high-resolution videos were recorded at 60 frames per second with the GoPro ${ }^{\circledR}$ camera along selected transect segments, and also were image-adjusted and corrected for lens distortion. Geotagged locations of 12,395 nadir photographs from the Drift ${ }^{\circledR}$ and GoPro ${ }^{\circledR}$ cameras were overlayed in a geographic information system (ArcMap 10.0) onto a map of 44 ecotypes (land- and water-cover types) of the Arctic Network study area. Presence and area of each ecotype occurring within a geographic information system window centered on the location of each photograph were recorded and included in the spreadsheet databases. All original and adjusted photographs, videos, geographic positioning system flight tracks, and photograph databases are available by contacting ascweb@usgs.gov.

\footnotetext{
${ }^{1}$ USDA Forest Service, Pacific Northwest Research Station, Portland OR; email: bmarcot@fs.fed.us.

${ }^{2}$ Alaska Ecoscience, Fairbanks, AK; email: ecoscience@alaska.net.

${ }^{3}$ U.S. Geological Survey, Alaska Science Center, Anchorage, AK; email: tdegange@usgs.gov.
} 


\section{Introduction}

Photography of land-cover conditions in arctic and boreal regions of Alaska has proven to be of great value for analyzing landscape changes from various local-to-regional causes (Swanson and Hill, 2010; Swanson 2012a, 2012b; Necsoiu and others, 2013). For example, a systematic 20-km grid of aerial photographs (Swanson, 2013) has provided information for estimating rates and causes of changes in land-cover types (vegetation, water). These estimates of transitional rates have been used in projecting potential effects of climate change on future land cover and implications for wildlife habitat throughout a large arctic and boreal region of northwest Alaska (DeGange and others, 2013). This project was initiated to complement the existing photographic databases by providing a set of high-resolution, natural-light images in continuous coverage along flight transects within the study area of northwest Alaska addressed by DeGange and others (2013).

\section{Description of Study Area}

The study area included five administrative units of the National Park Service Arctic Network (Bering Land Bridge National Preserve, Cape Krusenstern National Monument, Gates of the Arctic National Park and Preserve, Kobuk Valley National Park, and Noatak National Preserve), the adjacent area of U.S. Fish and Wildlife Service's Selawik National Wildlife Refuge, and a 10-km buffer around all these administrative units (fig. 1), totaling $162,868 \mathrm{~km}^{2}$ in an area spanning about $500 \mathrm{~km}$ from east to west and about $300 \mathrm{~km}$ from north to south. This also is the study area for the U.S. Geological Survey Wildlife Potential Habitat Forecasting Framework Project (WildCast) that projects effects of climate change on future land cover and wildlife habitat (DeGange and others, 2013).

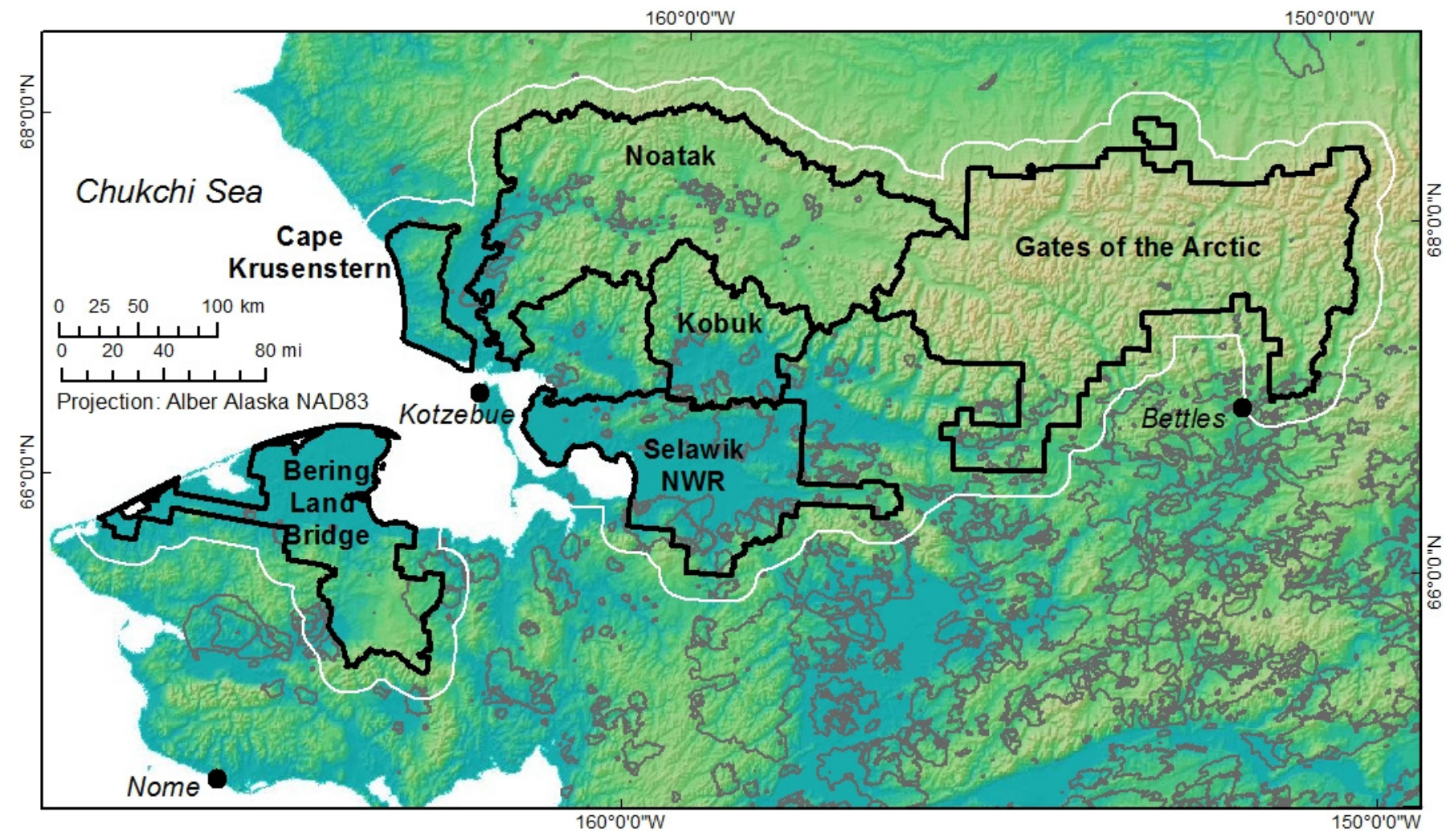

Figure 1. Study area in northwest Alaska comprising five national park units (black outlines) and one national wildlife refuge (NWR) and a surrounding 10-km buffer (white line). Historical fires since 1950 are shown in gray outlines and base map is a shaded-relief map using the U.S. Geological Survey National Elevation Dataset (300-m resolution, lower elevations in blue, higher elevations in yellow). 


\section{Methods}

Using the village of Kotzebue, Alaska, as a base of operations, we completed the project during 3 days of flights over the study area:

- July 16, 2013-Flight path over Bering Land Bridge National Preserve, with a Cessna 185 equipped with floats (ig. 2);
- July 17, 2013-Flight path over Kobuk Valley National Park, the western edge of Gates of the Arctic National Park and Preserve, and Selawik National Wildlife Refuge, with a Cessna 206 equipped with tundra tires (fig. 3); and

- July 18, 2013-Flight path over Noatak National Preserve and Cape Krusenstern National Monument, with a Cessna 206 equipped with tundra tires (fig. 4).

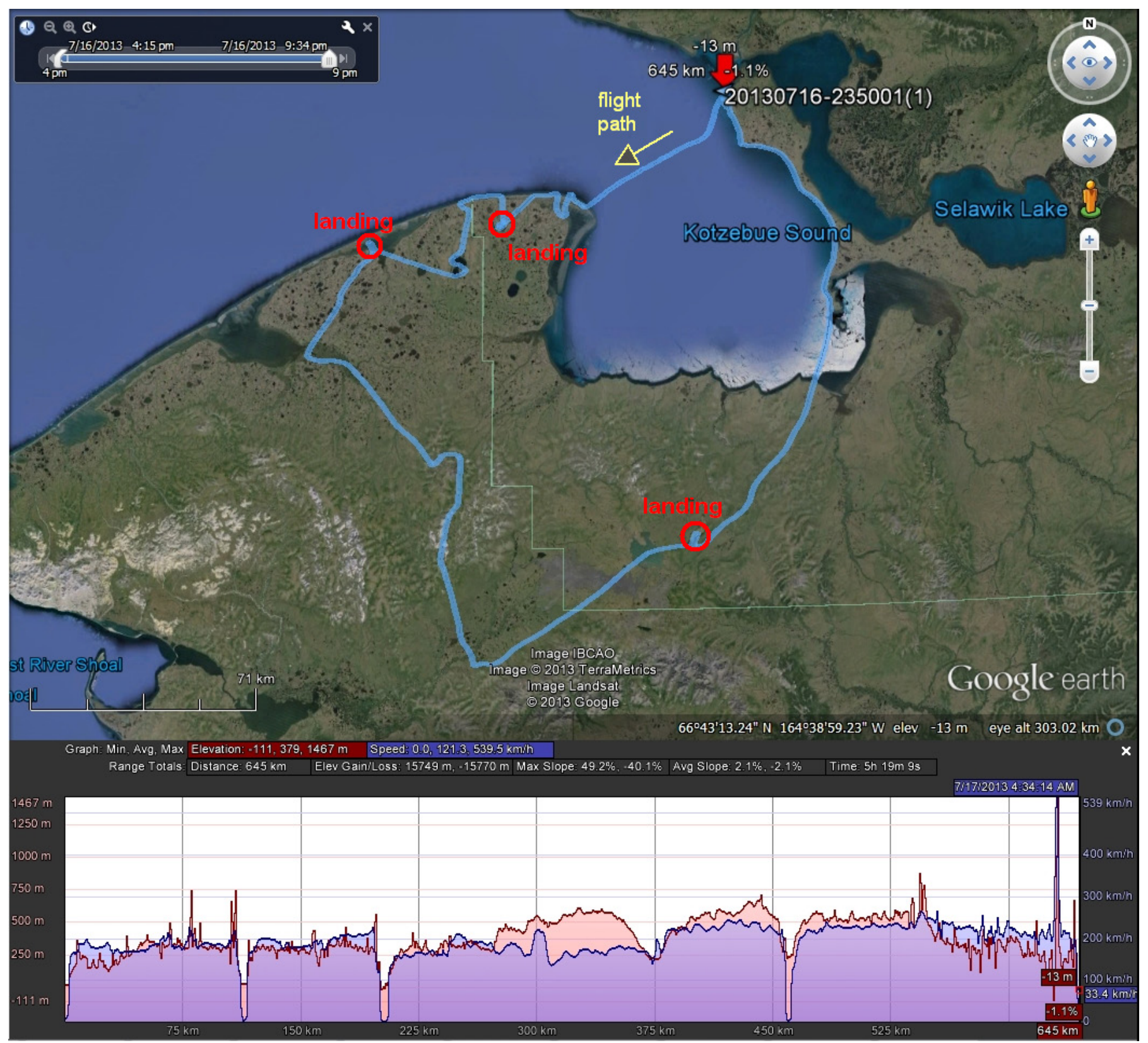

Figure 2. Flight path with altitude and speed profiles on July 16, 2013, over Bering Land Bridge National Preserve, northwest Alaska. Image source: Google Earth ${ }^{\circledR}$. 


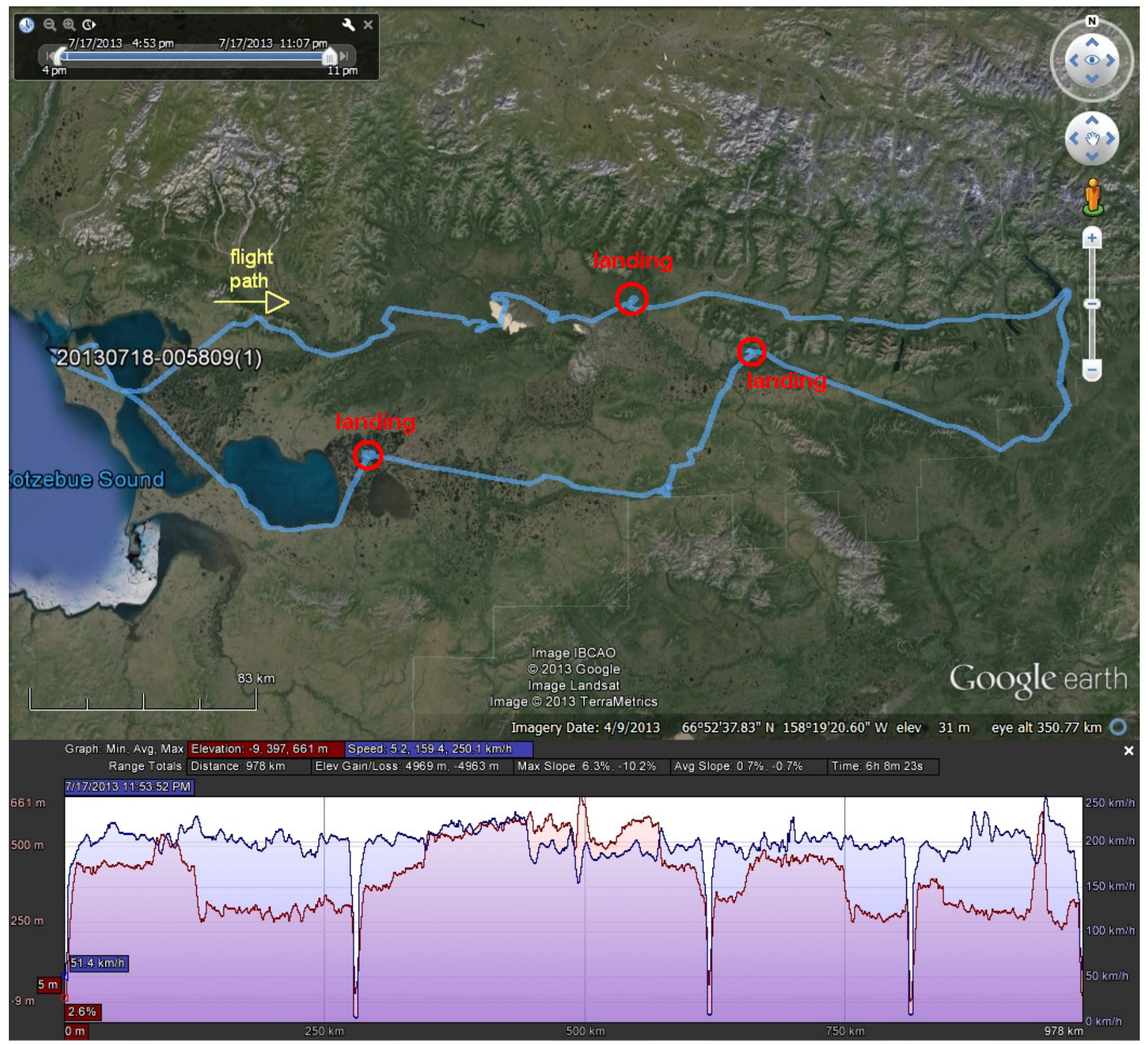

Figure 3. Flight path, with altitude and speed profiles on July 17, 2013, over Kobuk Valley National Park, Gates of the Arctic National Park and Preserve, and Selawik National Wildlife Refuge, northwest Alaska. Image source: Google Earth ${ }^{\circledR}$.

The specific flight routes were selected to provide a broad representation of ecotypes and land-cover types within each unit, as well as to overfly specific locations with thaw slumps, coastal erosion, and recent tundra fires (figs. 2- ). Each day's flight path consisted of four segments, as three landings were made each day (as shown in the altitude and speed profiles in figs. 2-4), including a landing to inspect and sample ground ice from an exposed pingo core in the northern part of Bering Land Bridge National Preserve.
During all flight segments, global positioning system (GPS) waypoints were recorded automatically at 5-second intervals using an i-gotU ${ }^{\circledR}$ GT-120 GPS waypoint data logger (table 1) mounted on the dashboard of each airplane, resulting in .gpx waypoint computer files (later converted to .csv files for analysis of waypoint statistics; see table 2). The .gpx files were imported into the @ trip PC ${ }^{\circledR}$ software (table 3) for locating each flight path, and then the GPS waypoint tracks were exported into Google Earth ${ }^{\circledR}$ (figs. 2-4) and saved as .kmz (compressed GPS route data) format. 


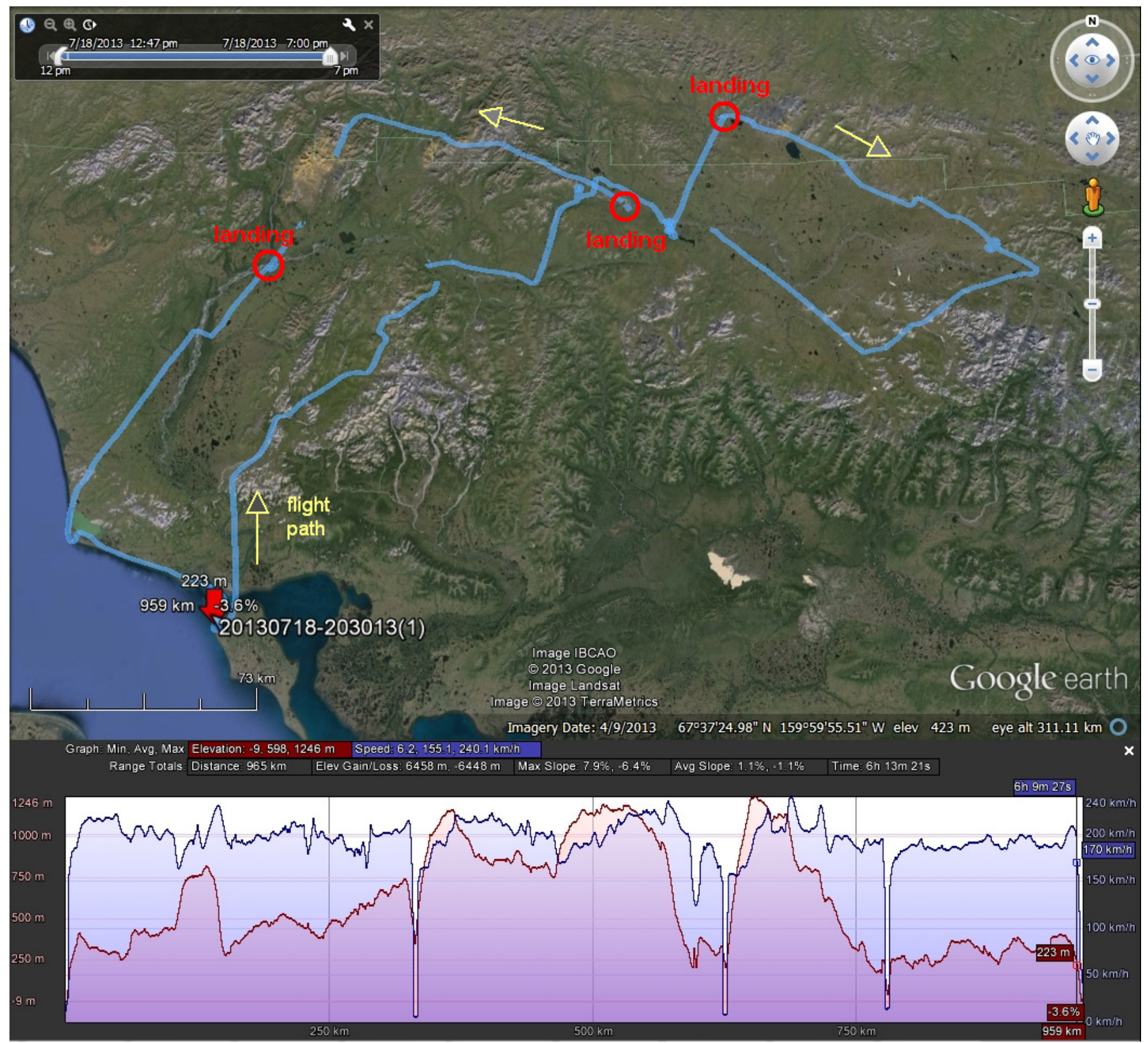

Figure 4. Flight transect route with altitude and speed profiles on July 18, 2013, over Noatak National Preserve and Cape Krusenstern National Monument, northwest Alaska. Image source: Google Earth ${ }^{\circledR}$. (The flight path is continuous; apparent interruptions are because of Google Earth ${ }^{\circledR}$ presentation.)

Five cameras were used for imaging (table 1):

1. A Drift ${ }^{\circledR} \mathrm{HD}-170$ (focal length $5.00 \mathrm{~mm}, 5 \mathrm{mp}$ resolution, $2592 \times 1944$ p, 4:3 aspect ratio, 24-bit color depth);

2. A GoPro ${ }^{\circledR}$ Hero3 Black Edition (focal length $2.77 \mathrm{~mm}$, 12 mp resolution, $4000 \times 3000$ p, 4:3 aspect ratio, 24-bit color depth);

3. A Panasonic ${ }^{\circledR}$ Lumix DMC-FZ200 (24× superzoom with various focal lengths, $12 \mathrm{mp}$ resolution, $4000 \times 3000 \mathrm{p}$, 4:3 aspect ratio, 24-bit color depth);
4. A Panasonic ${ }^{\circledR}$ Lumix DMC-SZ7 (10× superzoom with various focal lengths, $14 \mathrm{mp}$ resolution, $4320 \times 3240 \mathrm{p}$, 4:3 aspect ratio, 24-bit color depth); and

5. A Canon ${ }^{\circledR}$ Rebel 3Ti (with Sigma zoom lens 18-200 mm focal length, $18 \mathrm{mp}$ resolution, $5184 \times 3456 \mathrm{p}$, 3:2 aspect ratio, 24-bit color depth). 
Table 1. Hardware used for global positioning system (GPS) and photography.

\begin{tabular}{|c|c|}
\hline Unit & Positioning \\
\hline \multicolumn{2}{|c|}{ GPS } \\
\hline $\begin{array}{l}\text { i-gotU GT-120 GPS waypoint data logger (http://global.mobileaction. } \\
\text { com/product/product_i-gotU_USB.jsp), with external battery pack } \\
\text { (Brunton Inspire, www.brunton.com/products/inspire, 1000mA, } \\
\text { 11.8Wh) }\end{array}$ & $\begin{array}{l}\text { Positioned on the cockpit dashboard under the windshield for } \\
\text { unobstructed access to GPS satellite signals }\end{array}$ \\
\hline Garmin Oregon 550t hand-held GPS unit & Used on the ground and for backup GPS waypoint data \\
\hline \multicolumn{2}{|c|}{ Cameras } \\
\hline Drift ${ }^{\circledR}$ HD-170, with extra battery pack & Clamped onto the step strut for nadir imaging \\
\hline $\begin{array}{l}\text { GoPro }{ }^{\circledR} \text { Hero3 Black Edition, with supplemental battery unit and } \\
\text { extra battery packs }\end{array}$ & $\begin{array}{l}\text { Mounted on the tail strut (Cessna } 185 \text { with floats) or on the underwing } \\
\text { (Cessna } 206 \text { with tundra tires) for nadir imaging }\end{array}$ \\
\hline Panasonic ${ }^{\circledR}$ Lumix DMC-FZ200 24× superzoom & Hand-held within the cockpit for oblique to near-nadir photos \\
\hline Panasonic ${ }^{\circledR}$ Lumix DMC-FZ7 10× superzoom & Hand-held within the cockpit for oblique to near-nadir photos \\
\hline $\begin{array}{l}\text { Canon }{ }^{\circledR} \text { Rebel 3Ti with Sigma zoom lens (18-200 millimeter } \\
\text { focal length) }\end{array}$ & Hand-held within the cockpit for oblique to near-nadir photos \\
\hline
\end{tabular}

Table 2. Number of global positioning system (GPS) waypoints, number of photographs, and flight time and distance.

\begin{tabular}{|c|c|c|c|c|c|}
\hline & Track names & $\begin{array}{l}\text { ARCN } 130716 \\
\text { Bering LBNP }\end{array}$ & $\begin{array}{c}\text { ARCN } 130717 \\
\text { KobGatSel }\end{array}$ & $\begin{array}{c}\text { ARCN } 130718 \\
\text { NoaKru }\end{array}$ & Totals \\
\hline & Flight date & 07-16-13 & $07-17-13$ & 07-18-13 & 3 days \\
\hline & Number of waypoints ${ }^{1}$ & 1,354 & 9,902 & 9,905 & 21,161 \\
\hline \multirow{3}{*}{$\begin{array}{l}\text { Waypoint times } \\
\text { (hh:mm:ss) }\end{array}$} & Start & 23:15:05 & 23:53:52 & 19:47:04 & \\
\hline & End & 04:34:14 & 06:07:09 & 02:00:30 & \\
\hline & Elapsed & 5:19:09 & $6: 13: 17$ & $6: 13: 26$ & $17: 45: 52$ \\
\hline \multirow{6}{*}{$\begin{array}{c}\text { Number of photos } \\
\text { by camera }\end{array}$} & Drift $^{\circledR 3}$ & 2,427 & 2,839 & 3,460 & 8,726 \\
\hline & GoPro $^{\circledR 3}$ & 965 & 2,251 & 3,265 & 6,481 \\
\hline & Lumix FZ200 & 785 & 1,337 & 927 & 3,049 \\
\hline & Lumix S27 & 20 & 8 & 10 & 38 \\
\hline & Canon ${ }^{\circledR}$ Rebel & 224 & 352 & 297 & 873 \\
\hline & Totals & 4,421 & 6,787 & 7,959 & 19,167 \\
\hline \multirow[t]{2}{*}{ Flight distance } & kilometers & 645 & 980 & 965 & 2,590 \\
\hline & miles & 401 & 609 & 600 & 1,609 \\
\hline
\end{tabular}

${ }^{1}$ From the i-gotU GT-120 GPS waypoint data logger (see table 1).

${ }^{2}$ After deleting extraneous images.

${ }^{3}$ These cameras were affixed to the plane and set to 5 -second time-lapse operation (see appendix 1). 
Table 3. Software used to process project data.

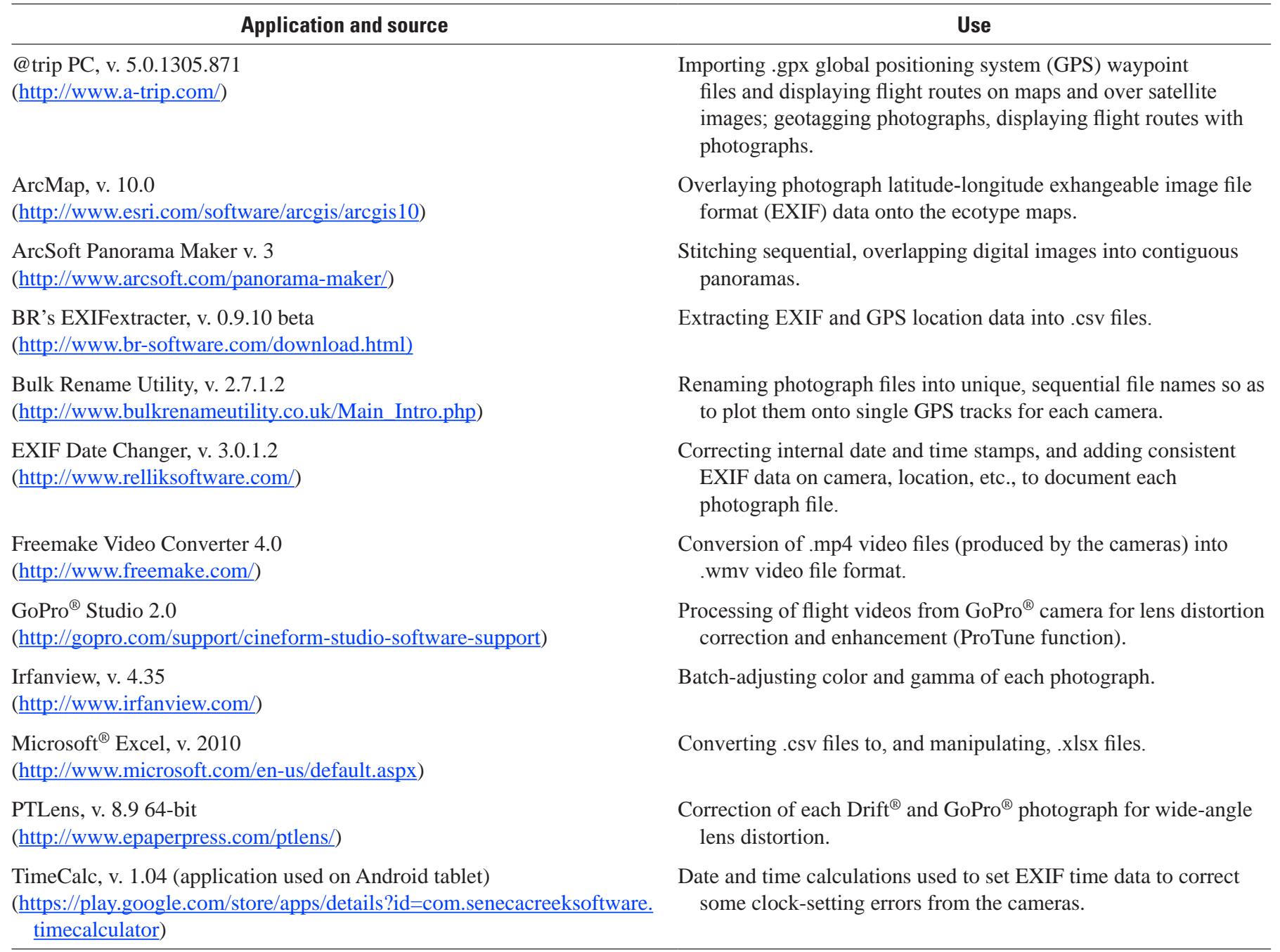

The Drift ${ }^{\circledR}$ HD-170 and GoPro ${ }^{\circledR}$ Hero3 cameras were secured to the struts and underwing for nadir (direct downward) imaging (fig. 5). The Panasonic ${ }^{\circledR}$ and Canon ${ }^{\circledR}$ cameras were each hand-held for oblique-angle landscape images, shooting through the airplanes' glass windows, targeting both general landscape conditions as well as landscape features of special interest, such as tundra fire scars and landslips.

The Drift ${ }^{\circledR}$ and GoPro ${ }^{\circledR}$ cameras were affixed to the airplane exteriors, and each was set for time-lapse photography at 5-second intervals (figs. 6-8) using their highest available resolution (5- and 12-mp, respectively). The 5-second time-lapse interval was calculated (appendix 1) as a function of the expected 300-m flight altitude above ground level (AGL), ground speed, the effective camera focal length after correction for lens distortion and cropping, and the desire to have about one-third overlap of adjacent photographs. Given the mean flight AGL and camera focal length, each resulting Drift ${ }^{\circledR}$ and GoPro ${ }^{\circledR}$ image covered about 71 ha of ground area (see appendix 3 for details on image and pixel sizes).
Additionally, as a demonstration of full continuous coverage, the GoPro ${ }^{\circledR}$ camera was set to video (movie) mode (focal length $2.77 \mathrm{~mm}, 1280 \mathrm{p} \times 720$ p, 16:9 aspect ratio, $60 \mathrm{fps}$ ) for flight segments in Bering Land Bridge National Preserve (fig. 6B) and Selawik National Wildlife Refuge (fig. 7D). The videos provided the opportunity for extracting individual frames for further analysis.

All photographs were processed as follows (see appendix 2 for details). First, photograph files were separated into folders on the computer, and renamed by flight date and camera type (table 4). Video files (.mp4 format also converted to .wmv) were processed separately from photographs. Next, extensively redundant or extraneous photographs were deleted, such as time-lapse images taken when the planes were stationary, long sequences taken over deep water (for example, over Kotzebue Sound), and other images with no usable content. 

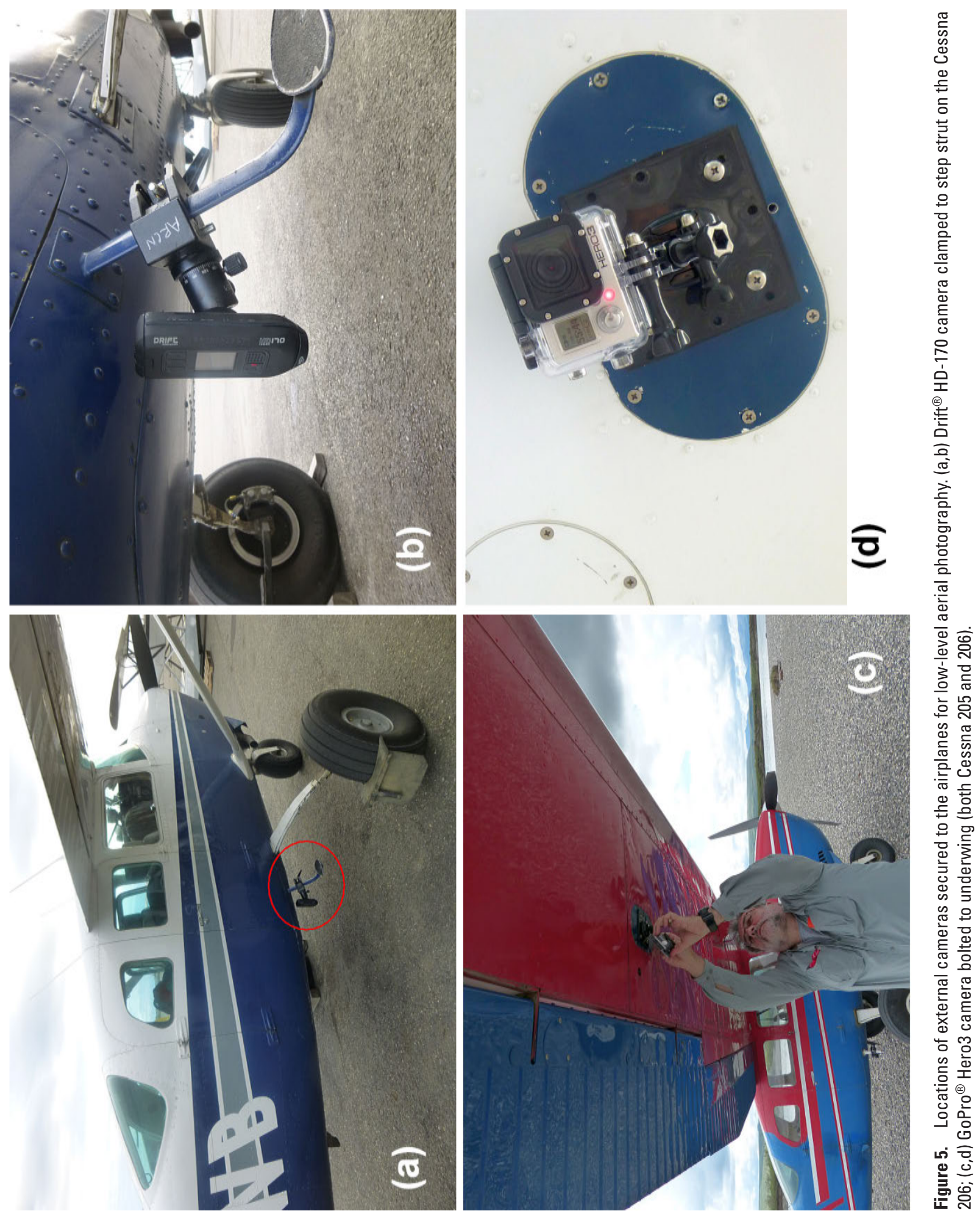


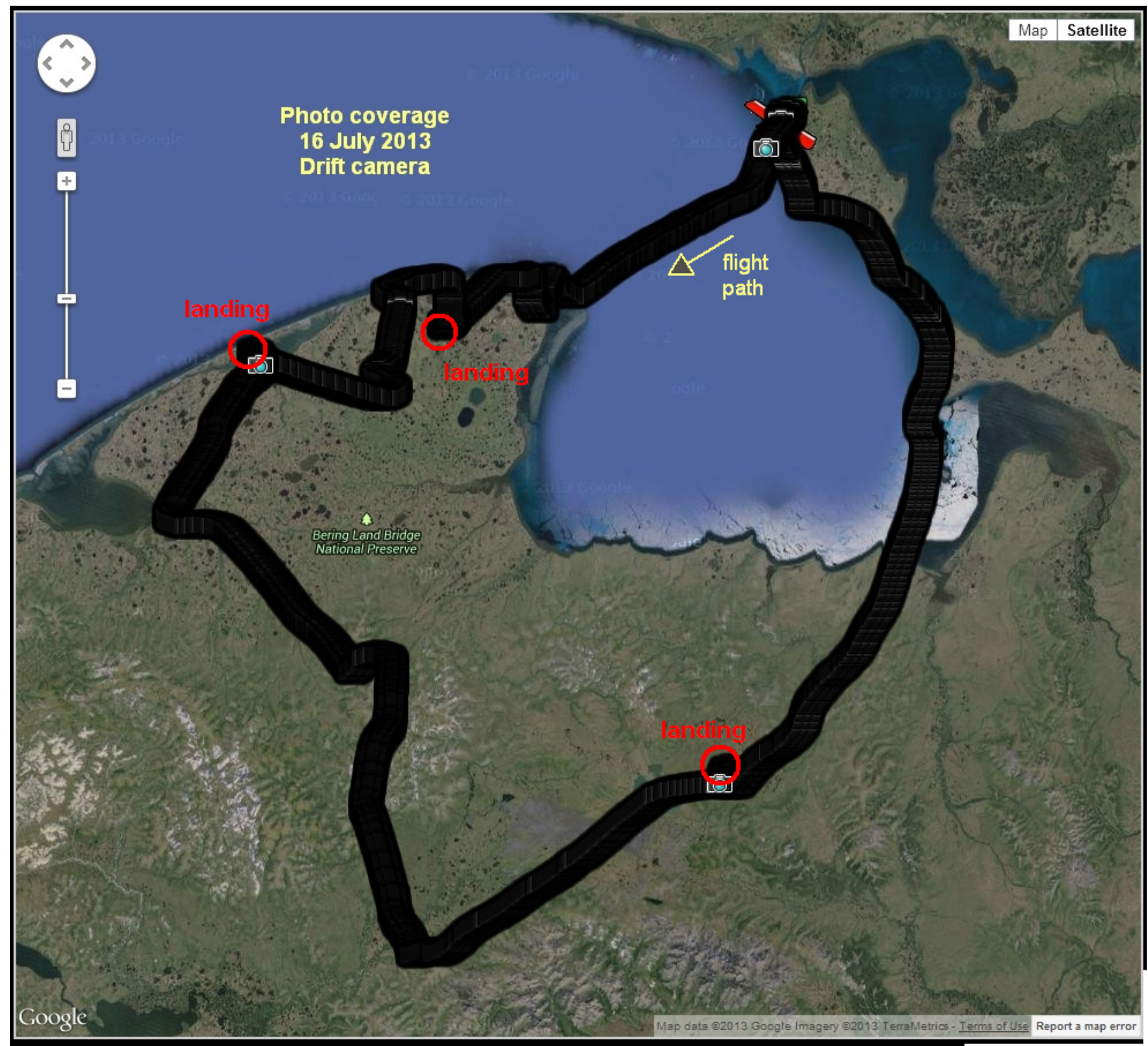

A. Drift $^{\circledR} \mathrm{HD}-170$ camera

Figure 6. Photographic coverage for July 16, 2013, of Bering Land Bridge National Preserve, northwest Alaska. (A) Drift ${ }^{\circledR}$ HD-170 camera, $(B)$ GoPro ${ }^{\circledR}$ Hero3 Black Edition camera, $(C)$ Panasonic ${ }^{\circledR}$ Lumix DMC-FZ200 camera, $(D)$ Canon ${ }^{\circledR}$ Rebel camera. Image produced by the software @trip PC ${ }^{\circledR}$ (see table 3). The dark black line denotes contiguous photography at 5-second intervals (small camera icons denote photography and are placed at random by the @trip PC ${ }^{\circledR}$ software). 


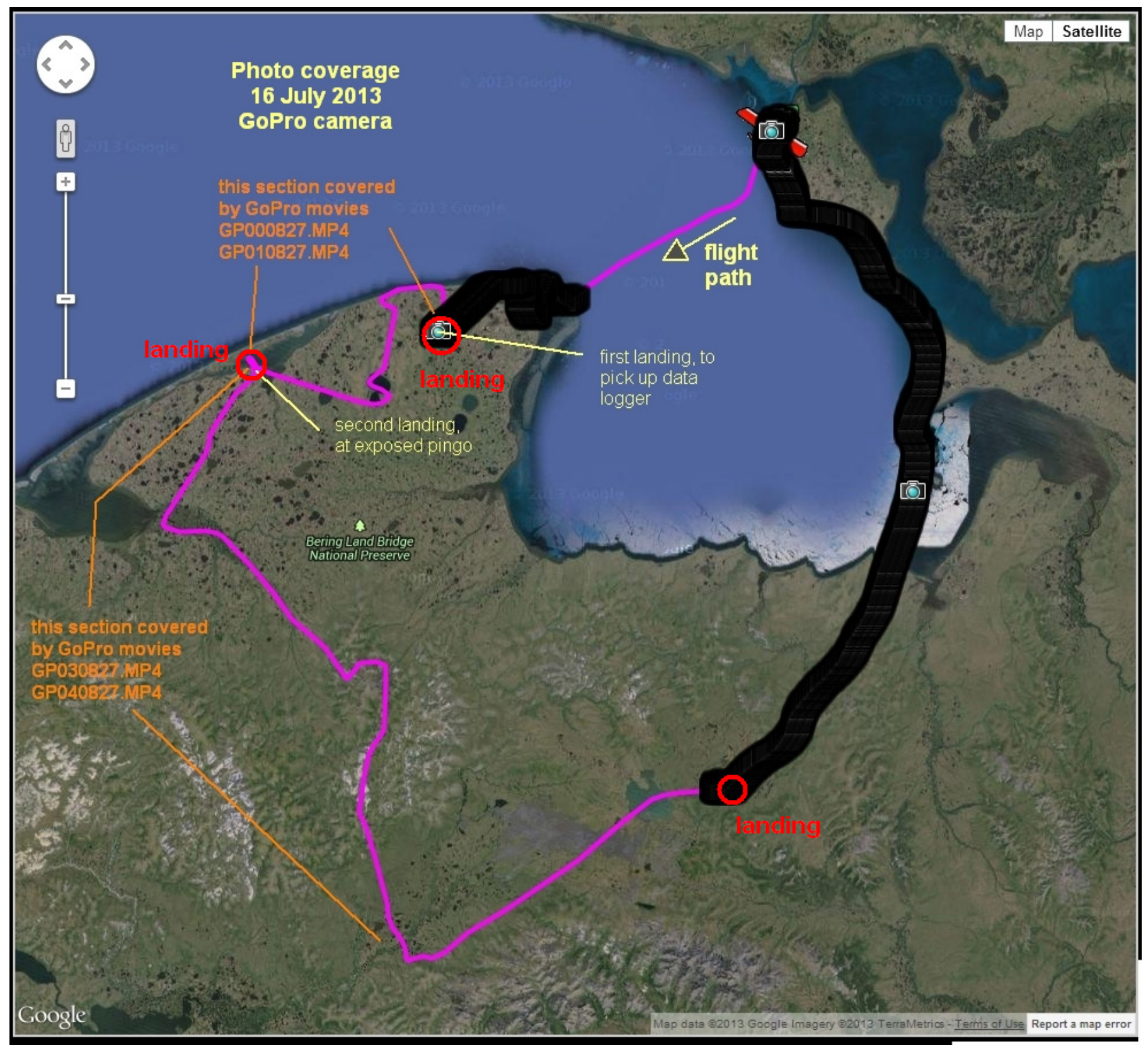

B. GoPro ${ }^{\circledR}$ Hero3 Black Edition camera

Figure 6.-Continued 


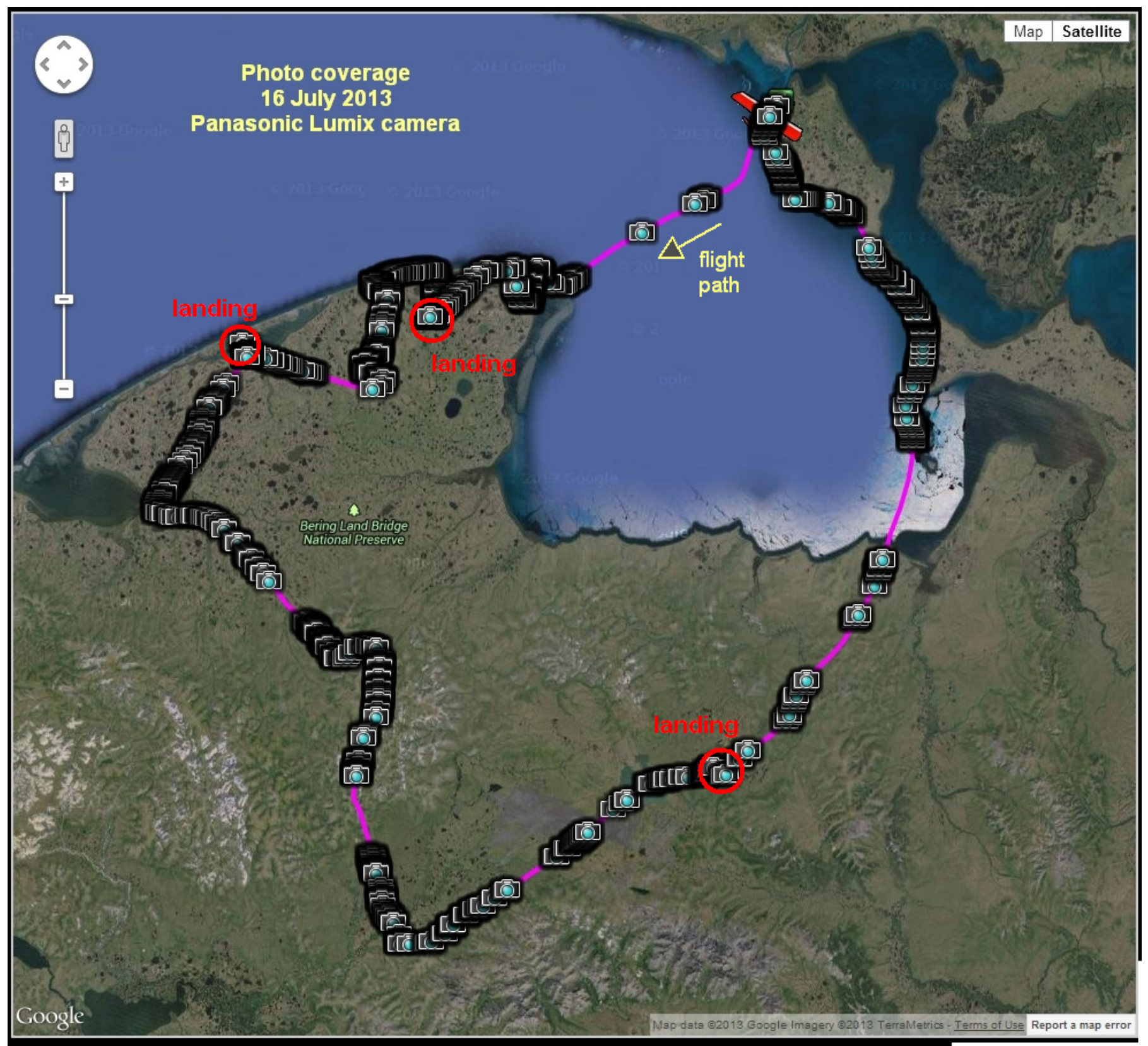

C. Panasonic ${ }^{\circledR}$ Lumix DMC-FZ200 camera

Figure 6.-Continued 


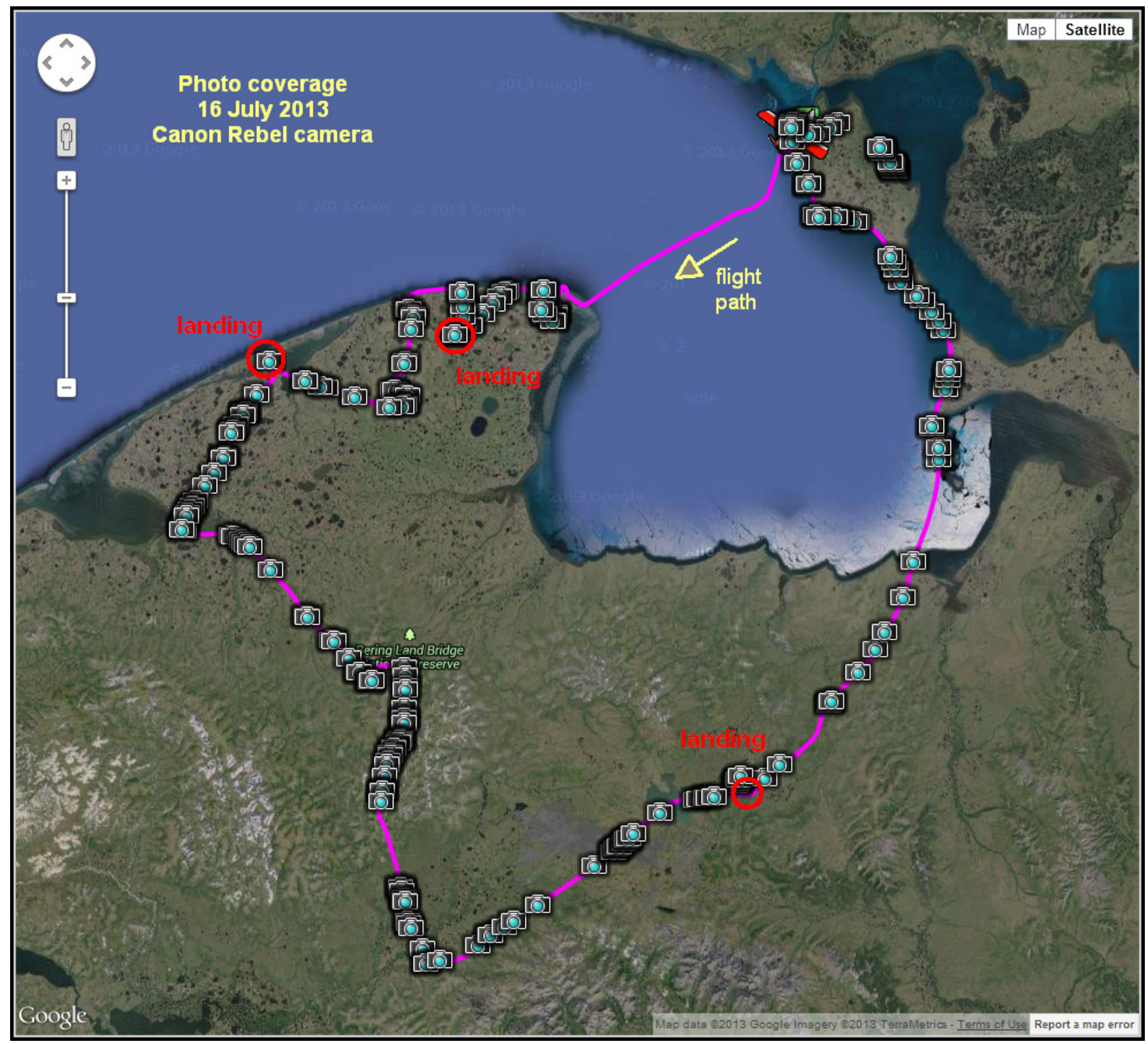

D. Canon $^{\circledR}$ Rebel camera

Figure 6.-Continued 


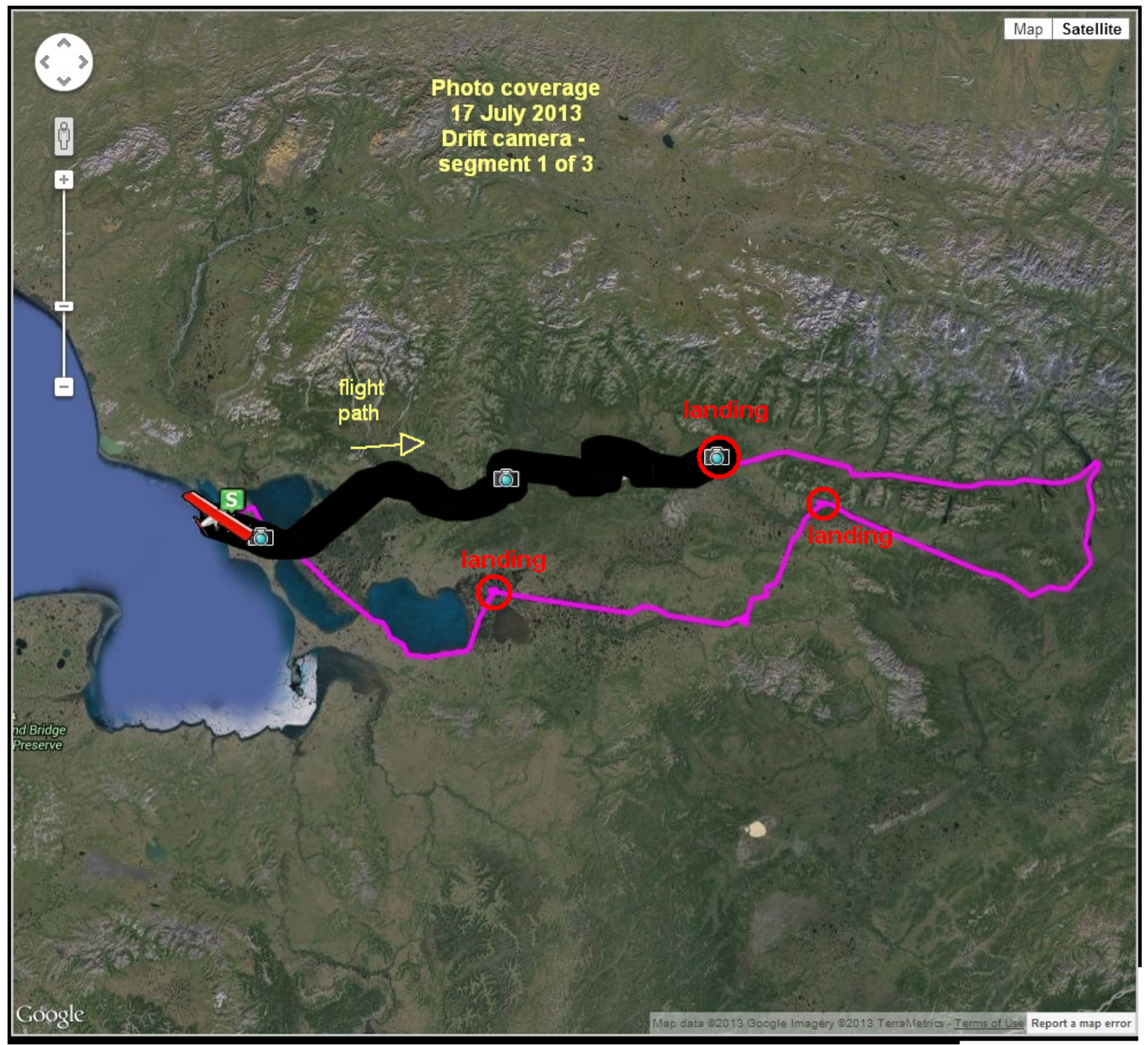

A. $\quad$ Drift ${ }^{\circledR}$ HD-170 camera, segment 1

Figure 7. Photographic coverage on July 17, 2013, of Kobuk Valley National Park, Gates of the Arctic National Park and Preserve, and Selawik National Wildlife Refuge, northwest Alaska. $(A-C)$ Drift ${ }^{\circledR}$ HD-170 camera, $(D)$ GoPro ${ }^{\circledR}$ Hero3 Black Edition camera, $(E)$ Panasonic ${ }^{\circledR}$ Lumix DMC-FZ200 camera, (F) Canon ${ }^{\circledR}$ Rebel camera. Image produced by the software @trip PC ${ }^{\circledR}$ (see table 3). The dark black line denotes contiguous photography at 5-second intervals (small camera icons denote photography and are placed at random by the @trip PC ${ }^{\circledR}$ software). 


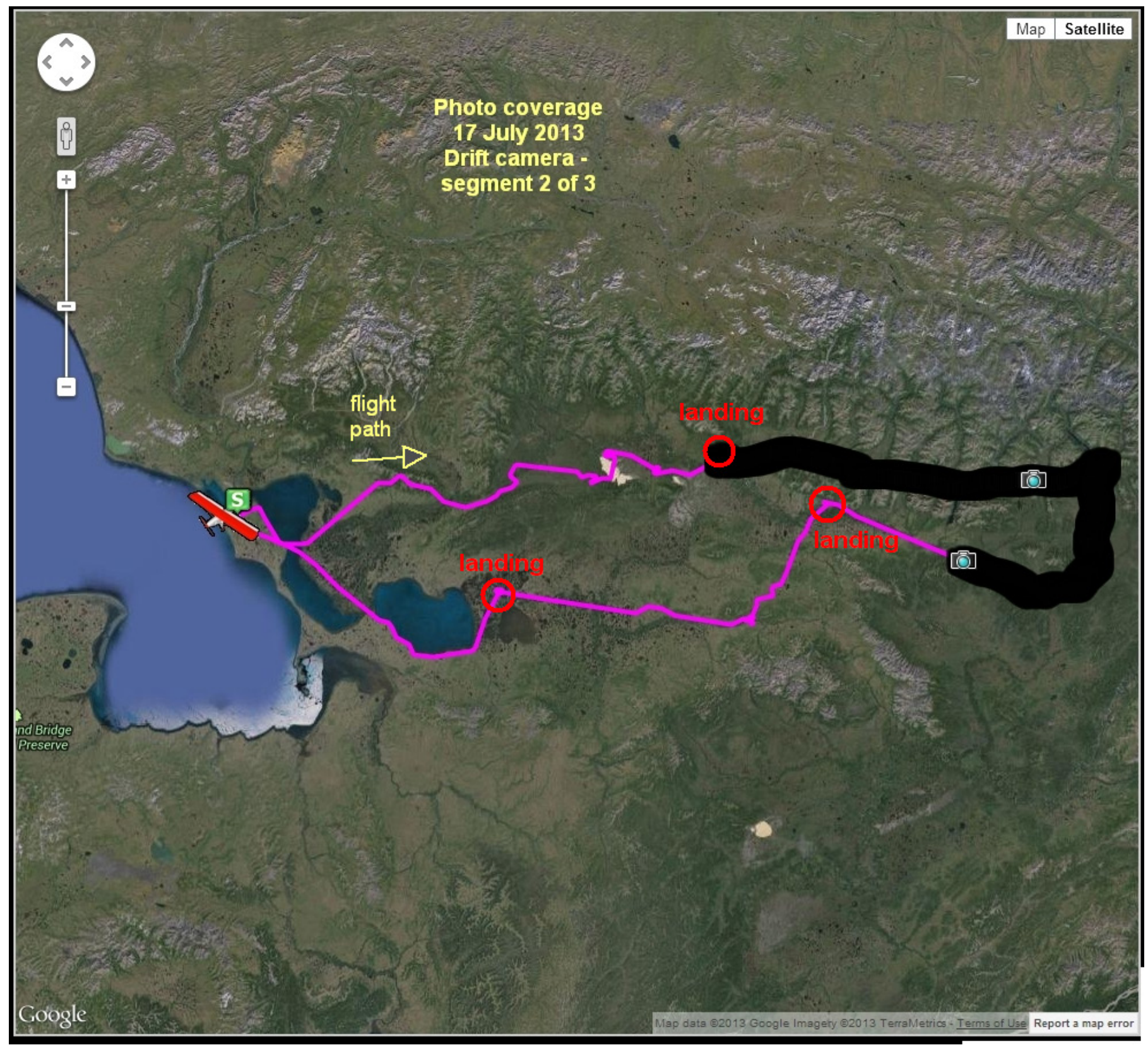

B. Drift $^{\circledR}$ HD-170 camera, segment 2

Figure 7.-Continued 


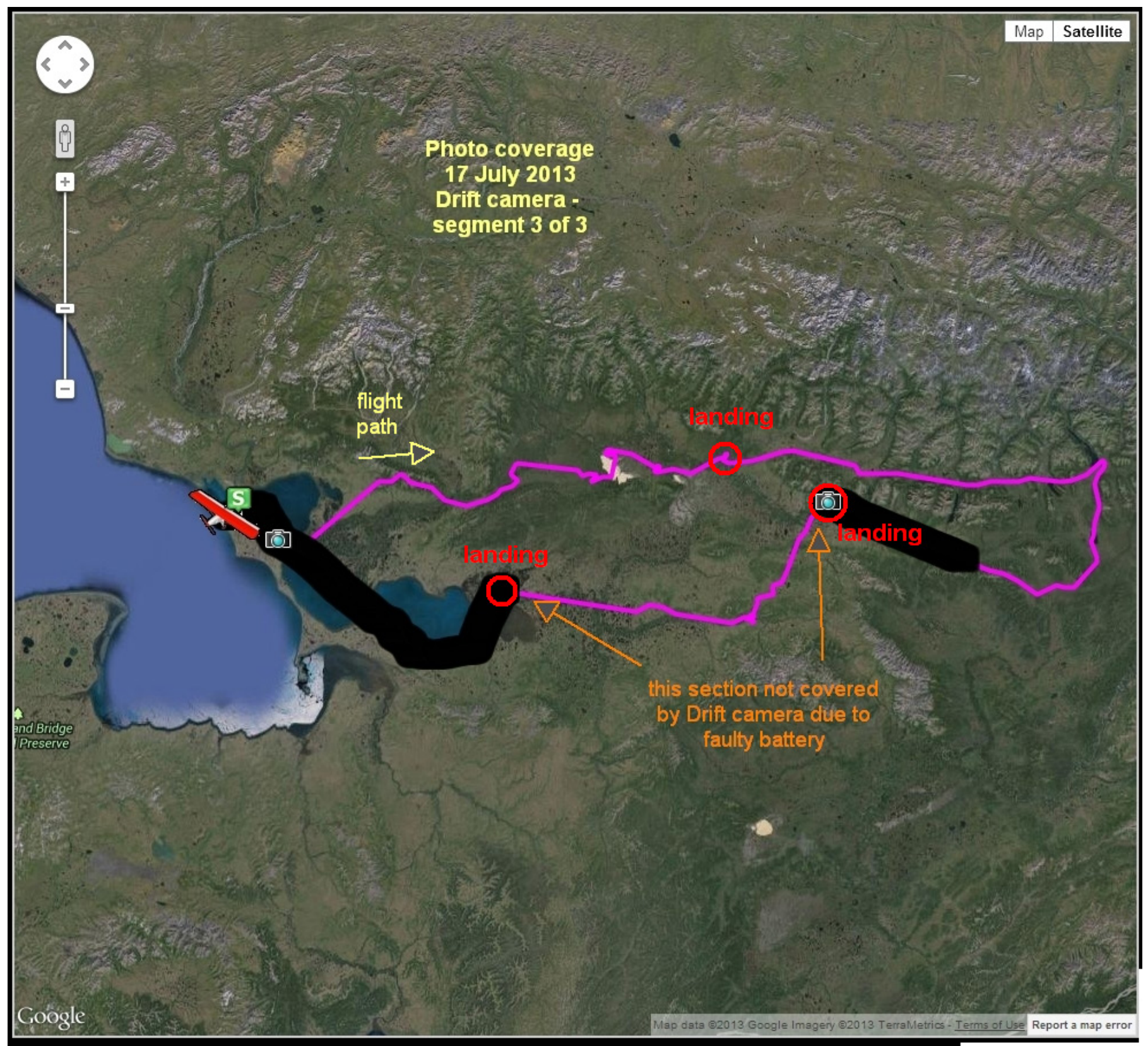

C. Drift $^{\circledR}$ HD-170 camera, segment 3

Figure 7.-Continued 


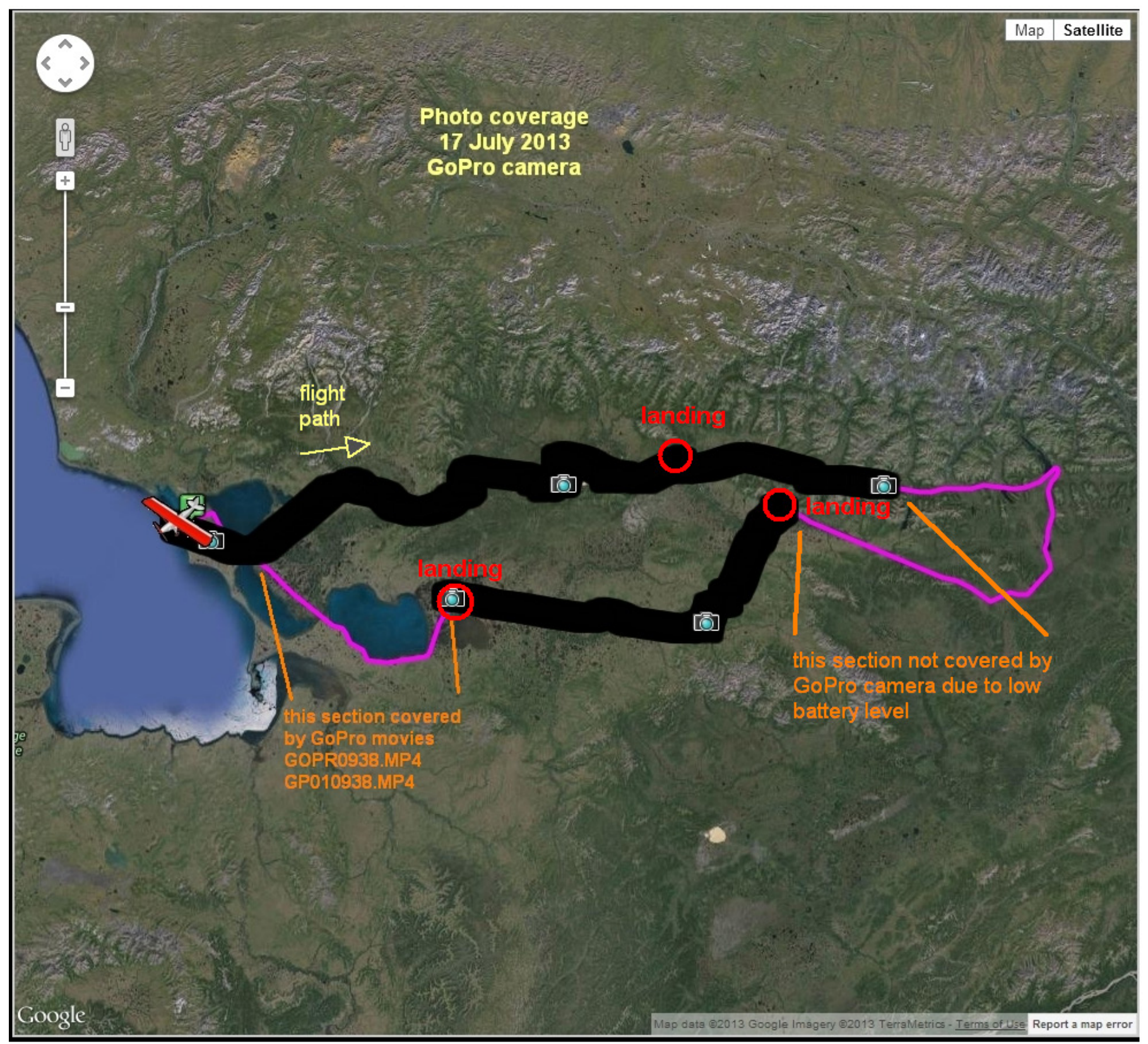

D. GoPro ${ }^{\circledR}$ Hero3 Black Edition camera

Figure 7.-Continued 


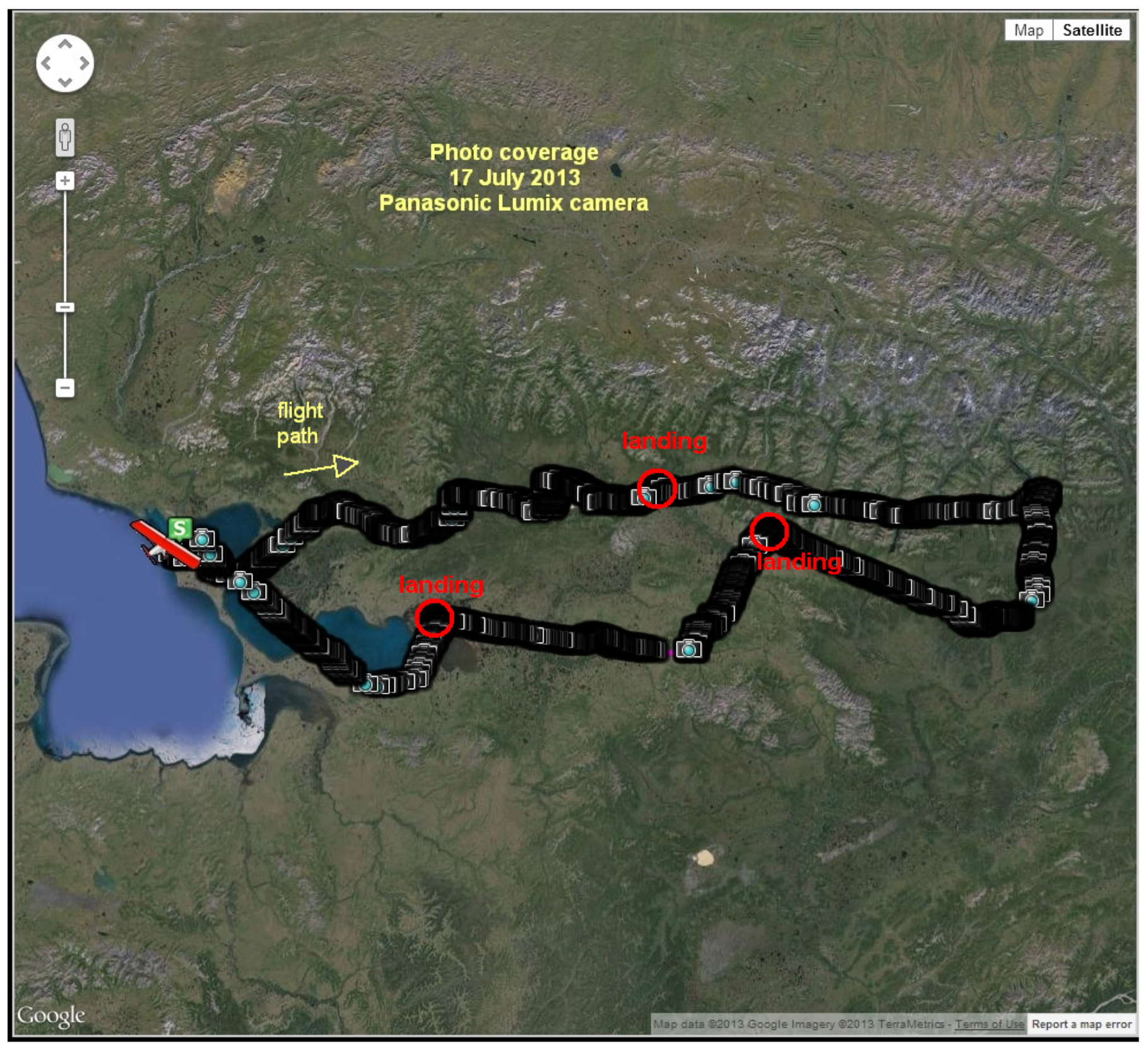

E. Panasonic ${ }^{\circledR}$ Lumix DMC-FZ200 camera

Figure 7.-Continued 


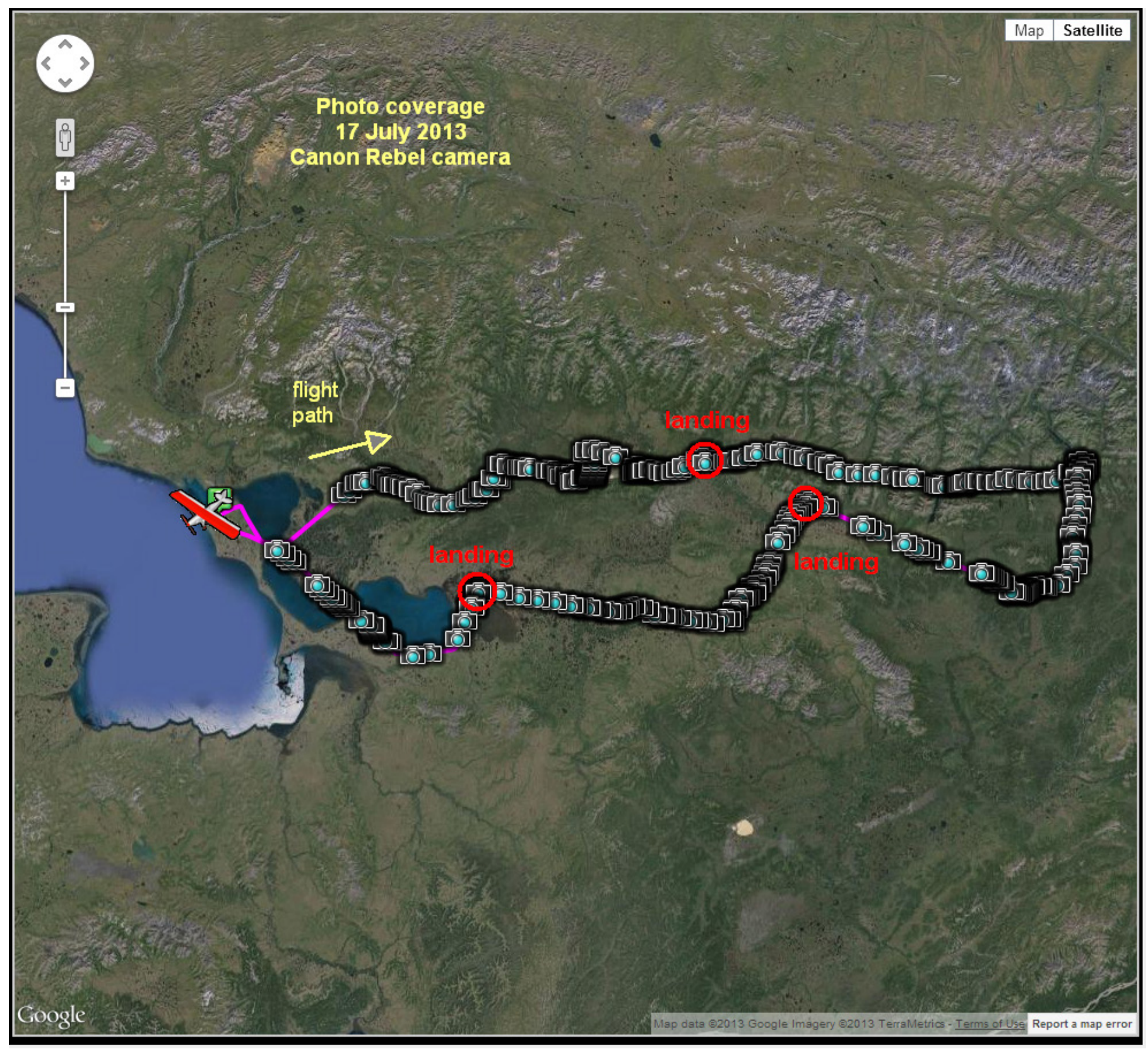

F. Canon ${ }^{\circledR}$ Rebel camera

Figure 7.-Continued 


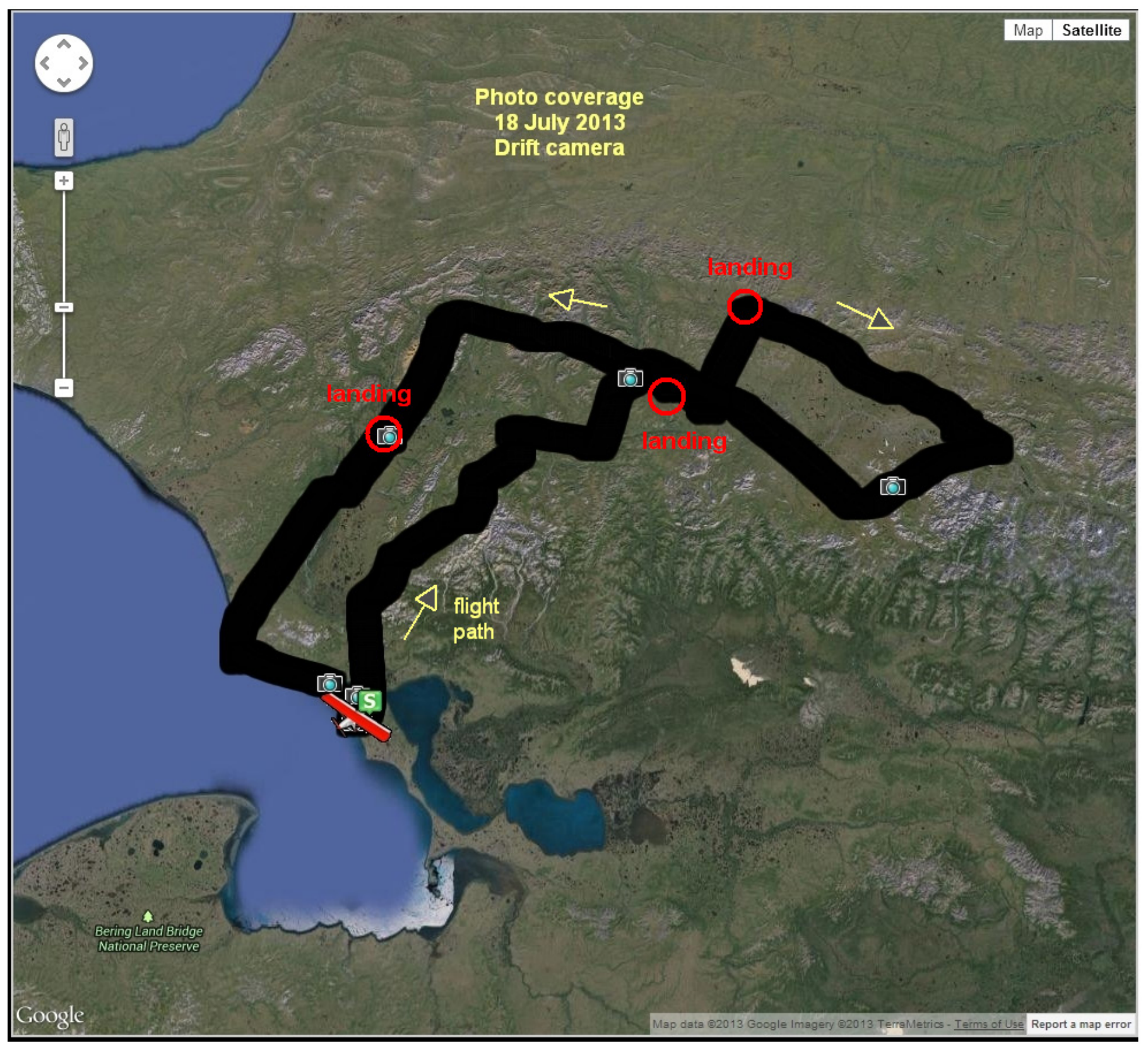

A. Drift $^{\circledR}$ HD-170 camera,

Figure 8. Photographic coverage, on July 18, 2013, of Noatak National Preserve and Cape Krusenstern National Monument, northwest Alaska. (A) Drift ${ }^{\circledR}$ HD-170 camera, $(B-D)$ GoPro ${ }^{\circledR}$ Hero3 Black Edition camera, $(E)$ Panasonic ${ }^{\circledR}$ Lumix DMC-FZ200 camera, $(F)$ Canon $^{\circledR}$ Rebel camera. Image produced by the software @trip PC ${ }^{\circledR}$ (see table 3). The dark black line denotes contiguous photography at 5 -second intervals (small camera icons denote photography and are placed at random by the @trip PC ${ }^{\circledR}$ software). 


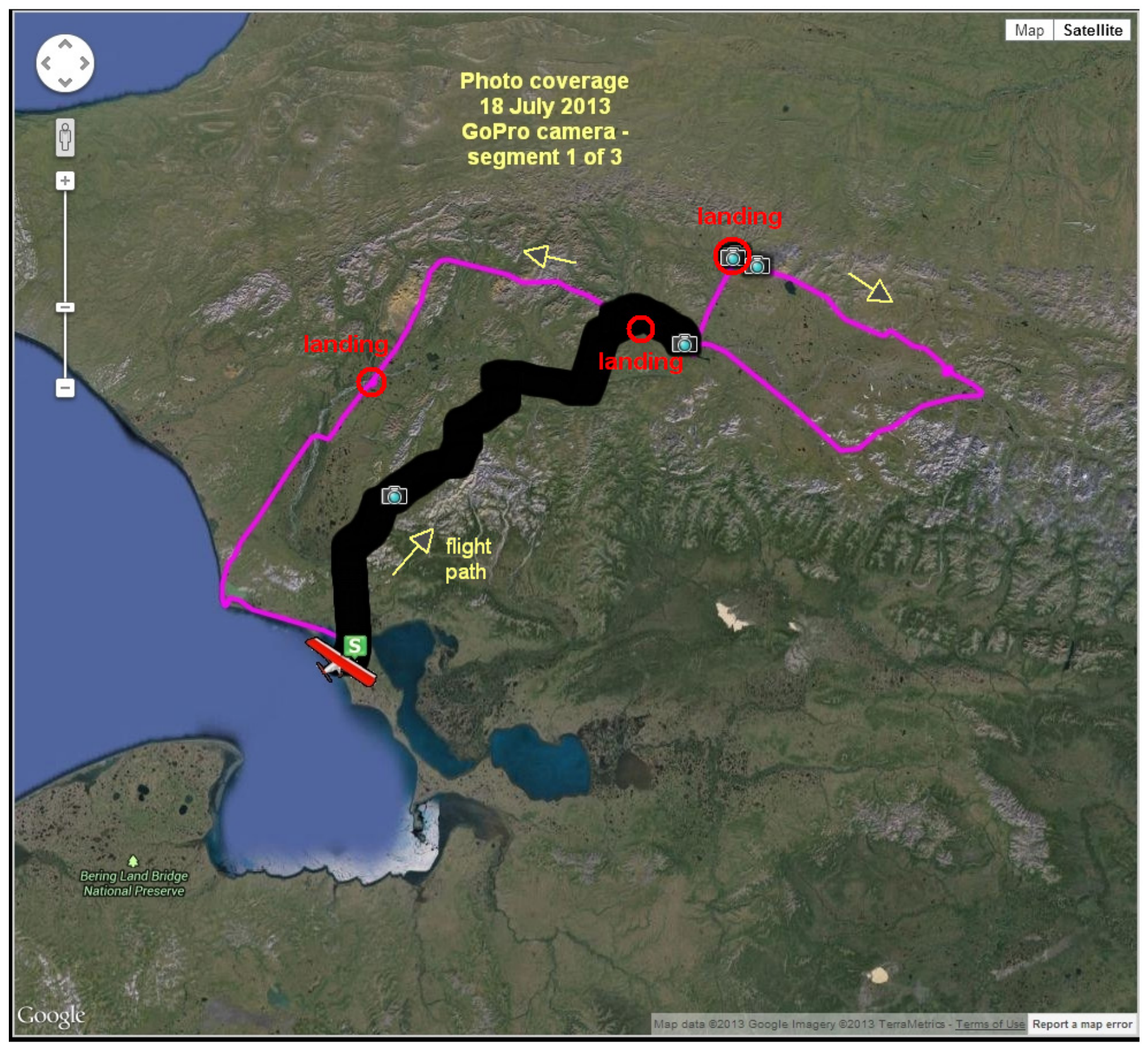

B. GoPro ${ }^{\circledR}$ Hero3 Black Edition camera, segment 1

Figure 8.-Continued 


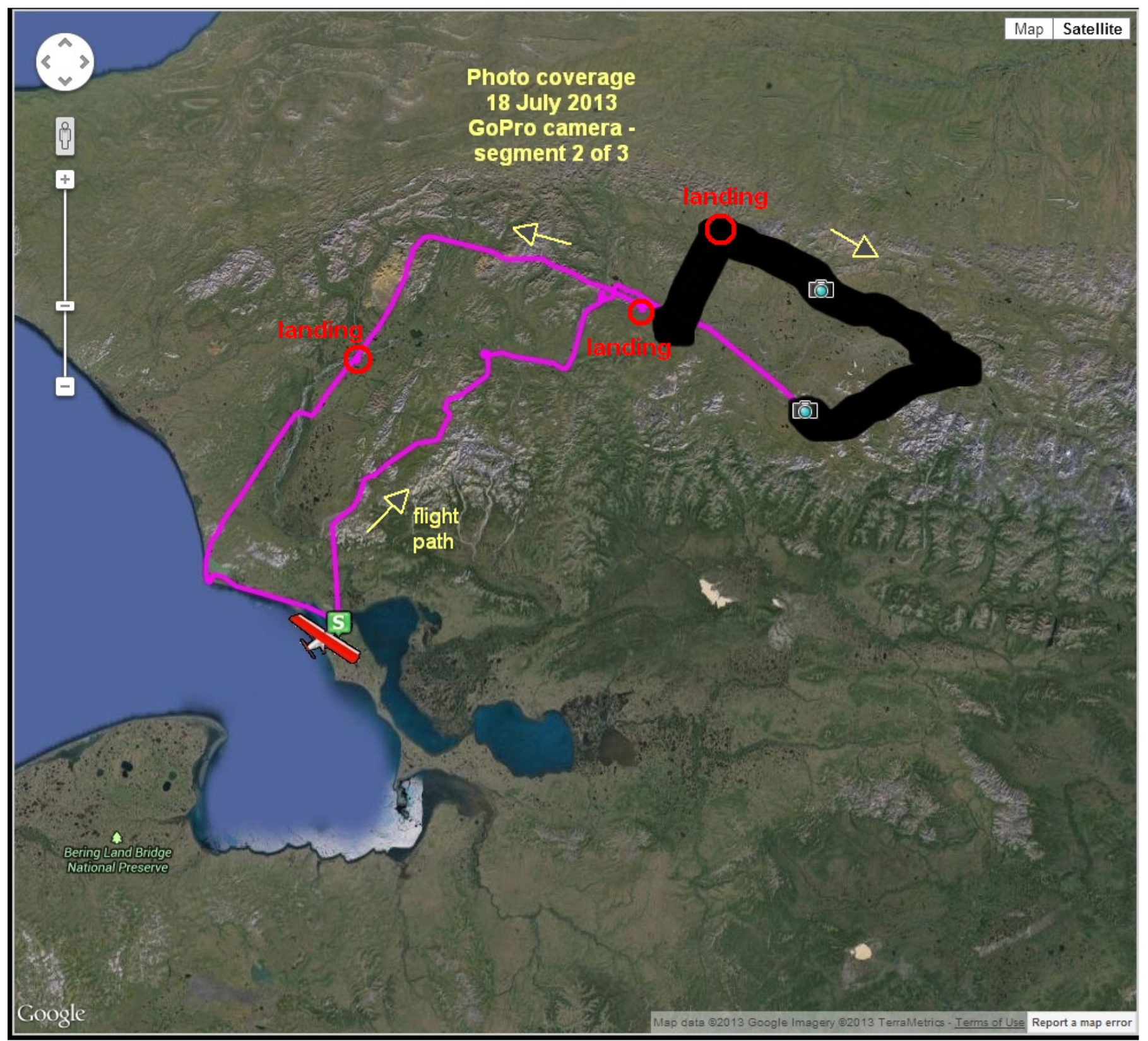

C. GoPro ${ }^{\circledR}$ Hero3 Black Edition camera, segment 2

Figure 8.-Continued 


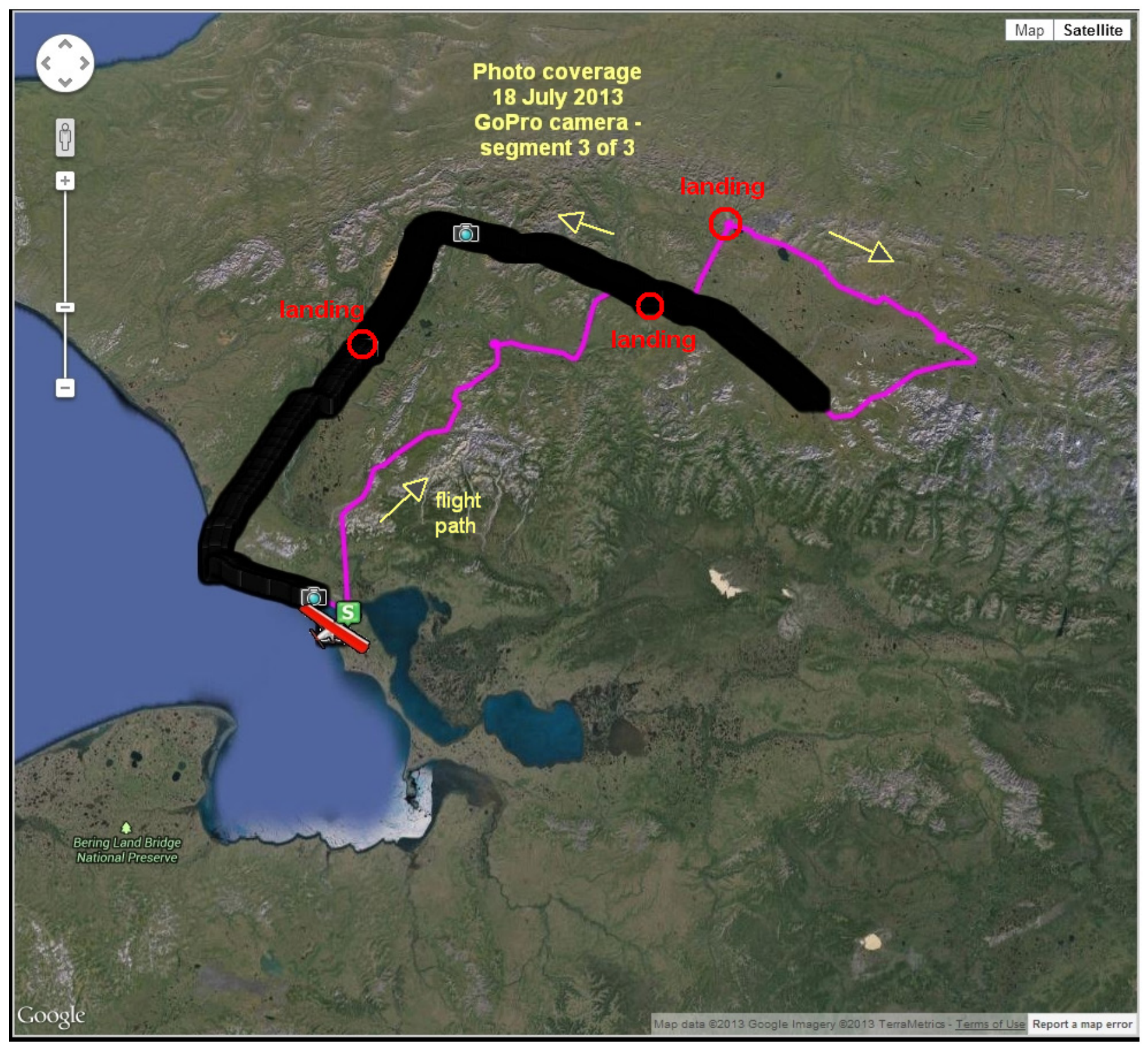

D. GoPro ${ }^{\circledR}$ Hero3 Black Edition camera, segment 3

Figure 8.-Continued 


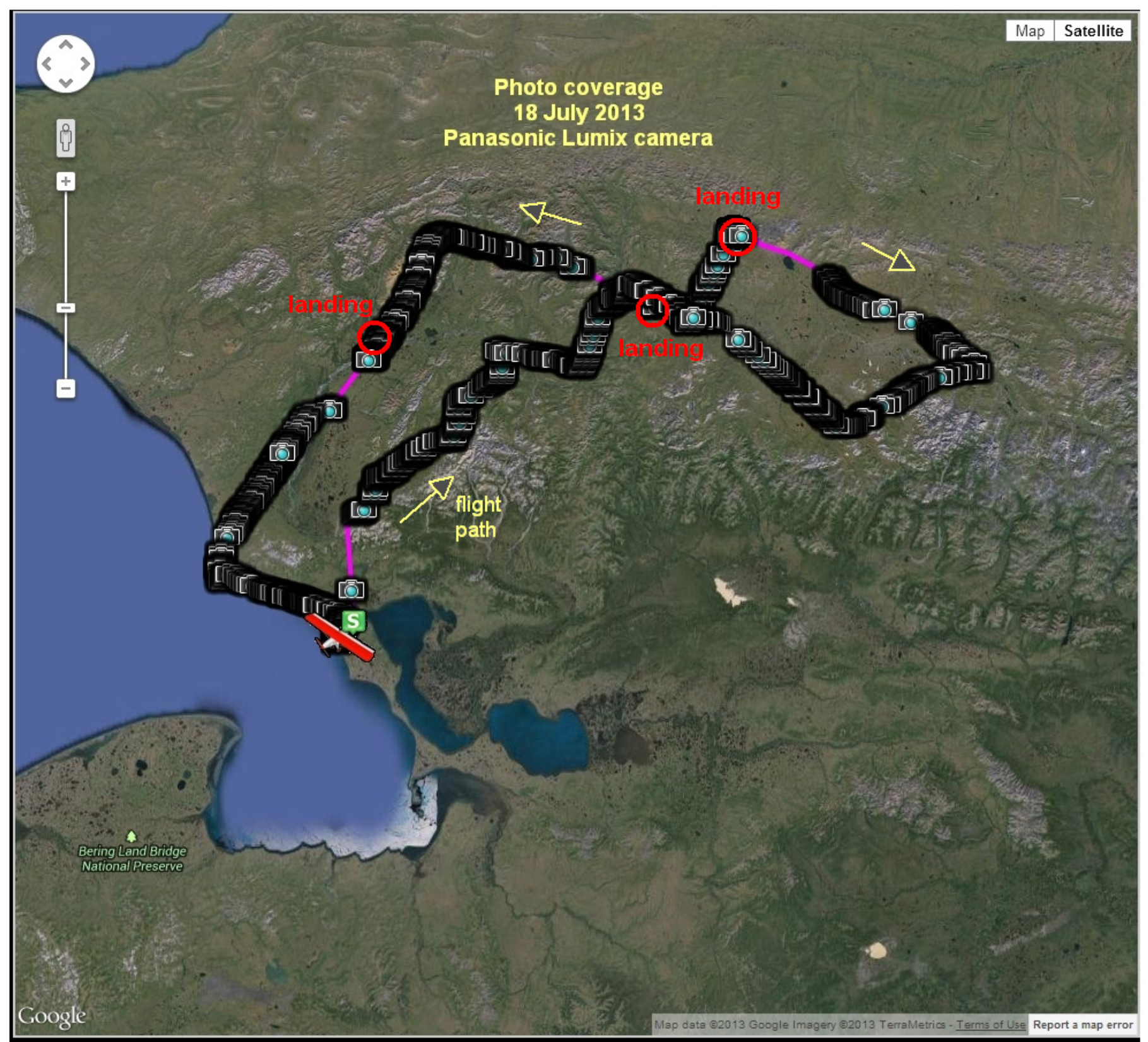

E. Panasonic ${ }^{\circledR}$ Lumix DMC-FZ200 camera

Figure 8.-Continued 


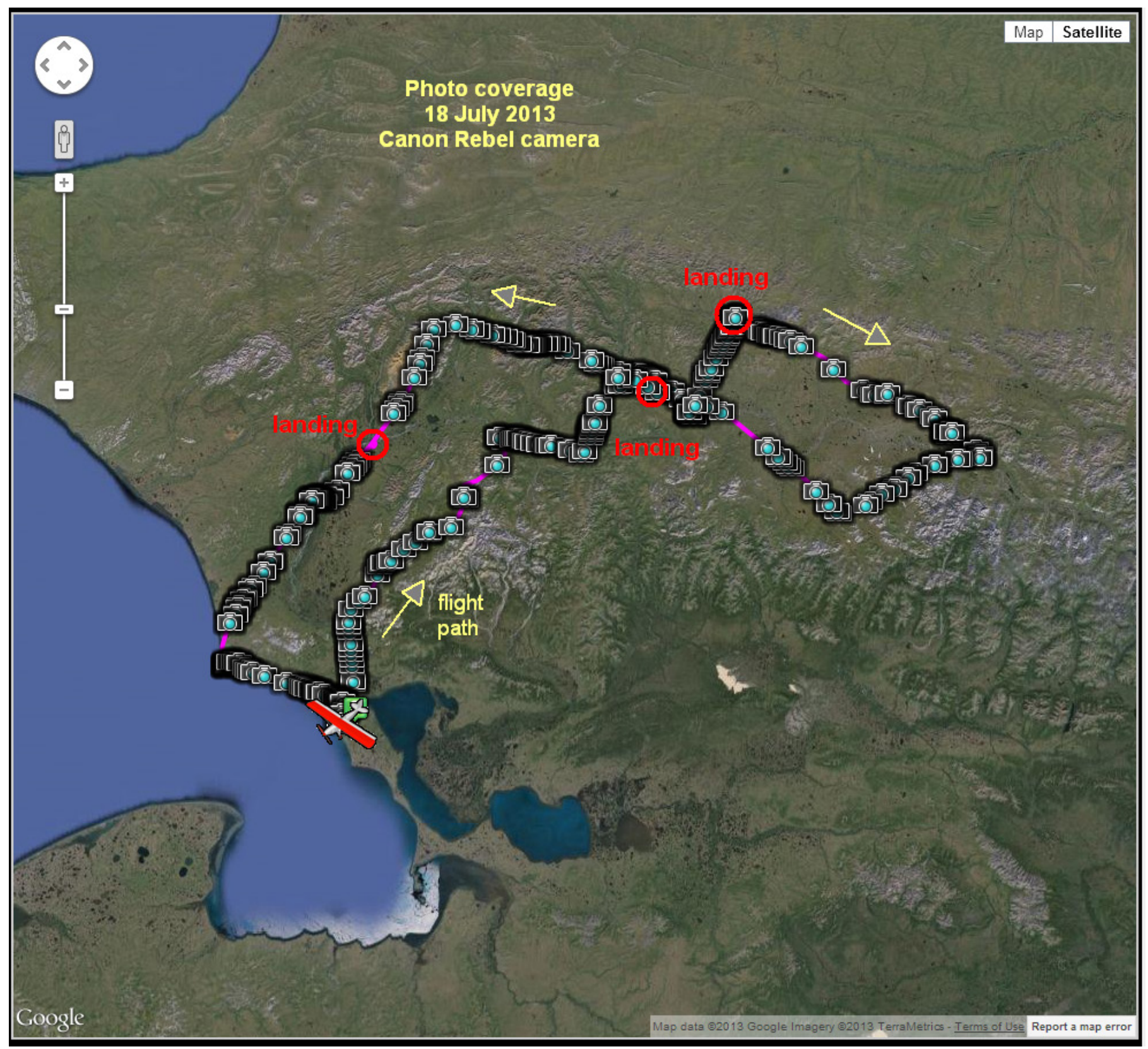

F. $\quad$ Canon ${ }^{\circledR}$ Rebel camera

Figure 8.-Continued 
Table 4. Naming convention of photographs and their computer subdirectories.

[Computer subdirectory name: Location Bering, Bering Land Bridge National Preserve; Gat, Gates of the Arctic National Park and Preserve; Kob, Kobuk Valley National Park; Kru, Cape Krusenstern National Monument; Noa, Noatak National Preserve; Sel, Selawik National Wildlife Refuge. Cameras used: Drift, Drift ${ }^{\circledR}$ HD-170 camera; GoPro, GoPro ${ }^{\circledR}$ Hero3 Black Edition camera; Lumix, Panasonic ${ }^{\circledR}$ Lumix DMC-FZ200 superzoom camera; LumixSZ7, Panasonic ${ }^{\circledR}$ Lumix DMC-SZ7 superzoom camera; Canon, Canon Rebel 3Ti. File name template: ARCN, National Park Service Arctic Network; 13071d, yymmdd flight date $(130716,130717,130718)$; xxxx, photograph file number $(0001,0002, \ldots)]$

\begin{tabular}{|c|c|}
\hline Computer subdirectory name & File name template \\
\hline AARCN Photos 130716 Bering $\backslash$ Drift ${ }^{\circledR}$ HD170 & ARCN 130716 Bering, Drift ${ }^{\circledR}$ xxxx \\
\hline 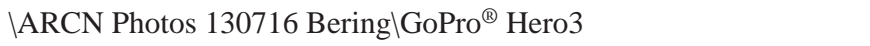 & ARCN 130716 Bering, GoPro ${ }^{\circledR}$ xxxx \\
\hline$\backslash$ ARCN Photos 130716 Bering \Panasonic ${ }^{\circledR}$ Lumix DMC-SZ7 & ARCN 130716 Bering, LumixSZ7 xxxx \\
\hline$\backslash$ ARCN Photos 130716 Bering \Canon ${ }^{\circledR}$ Rebel & ARCN 130716 Bering, Canon ${ }^{\circledR}$ xxxx \\
\hline$\backslash$ ARCN Photos 130717 KobGatSel\Drift ${ }^{\circledR}$ HD170 & ARCN 130717 KobGatSel, Drift ${ }^{\circledR} \mathrm{xxxx}$ \\
\hline \ARCN Photos 130717 KobGatSel\Panasonic ${ }^{\circledR}$ Lumix DMC-FZ200 & ARCN 130717 KobGatSel, Lumix xxxx \\
\hline \ARCN Photos 130717 KobGatSel\Panasonic ${ }^{\circledR}$ Lumix DMC-SZ7 & ARCN 130717 KobGatSel, LumixSZ7 xxxx \\
\hline$\backslash$ ARCN Photos 130717 KobGatSel\Canon ${ }^{\circledR}$ Rebel & ARCN 130717 KobGatSel, Canon ${ }^{\circledR}$ xxxx \\
\hline \ARCN Photos 130718 NoaKrulDrift ${ }^{\circledR}$ HD170 & ARCN 130718 NoaKru, Drift ${ }^{\circledR} \mathrm{xxxx}$ \\
\hline \ARCN Photos 130718 NoaKru $\backslash$ GoPro ${ }^{\circledR}$ Hero3 & ARCN 130718 NoaKru, GoPro ${ }^{\circledR}$ xxxx \\
\hline
\end{tabular}

The next step entailed ensuring that date and time in each photograph file's EXIF (exchangeable image file format) data were accurate, as these data linked to the GPS waypoints for geotagging each photograph. Next, each photograph was adjusted for color saturation and gamma (appendix 2), which highlighted many details. Each nadir photograph (Drift ${ }^{\circledR}$ and GoPro ${ }^{\circledR}$ cameras) then was corrected for lens distortion to adjust for the wide-angle $\left(170^{\circ}\right.$ fisheye) distortion that occurred from the small focal lengths, and was cropped to exclude blank portions of the image that occur after fisheye correction (fig. 9). Images from the hand-held Panasonic ${ }^{\circledR}$ and Canon ${ }^{\circledR}$ cameras were not corrected for lens distortion, as those photographs were taken at various oblique angles and focal lengths (zoom levels) from inside the airplane cabin. Each nadir video from the GoPro ${ }^{\circledR}$ camera also was processed for lens distortion correction and color and gamma enhancement.

Next, EXIF data from all photograph files_-including photograph file name and computer directory name, photograph date and time, camera type and settings, geotagged digital latitude and longitude, and altitude above mean sea level-were extracted into spreadsheet files (.xlsx formats) by flight date and camera type.
The geolocation (latitude and longitude) of each nadir photograph from the Drift ${ }^{\circledR}$ and GoPro ${ }^{\circledR}$ cameras was overlaid in GIS (ArcMap ${ }^{\circledR} 10.0$; table 3) onto a map of 44 ecotypes of the ARCN region (Jorgenson and others, 2009). Presence and area of each ecotype within a square window centered on each photograph location were recorded and included in the EXIF spreadsheet files (see appendix 3 for details). Because of the continual time-lapse coverage along the flight routes, not every nadir photograph was taken within the ARCN study area (fig. 1); therefore, not every nadir photograph has associated mapped ecotypes. An example of nadir photographs without associated ecotypes are those taken during the portion of the flight route on July 16, 2013, in Bering Land Bridge National Preserve that occurred east of that area's buffer en route north back to Kotzebue (fig. 2).

The individual photograph geolocations also were intersected in GIS with a digital elevation model (DEM) of the ARCN study area so that ground-level elevation could be determined for each photograph location (appendix 4). Finally, the difference between flight altitude above mean sea level (determined en route by the on-board GPS unit) and groundlevel elevation gave flight altitude above ground level for all photographs, which was used to verify the mean flight altitude used in the calculations of photograph time-lapse intervals and areal coverage of each photograph. 

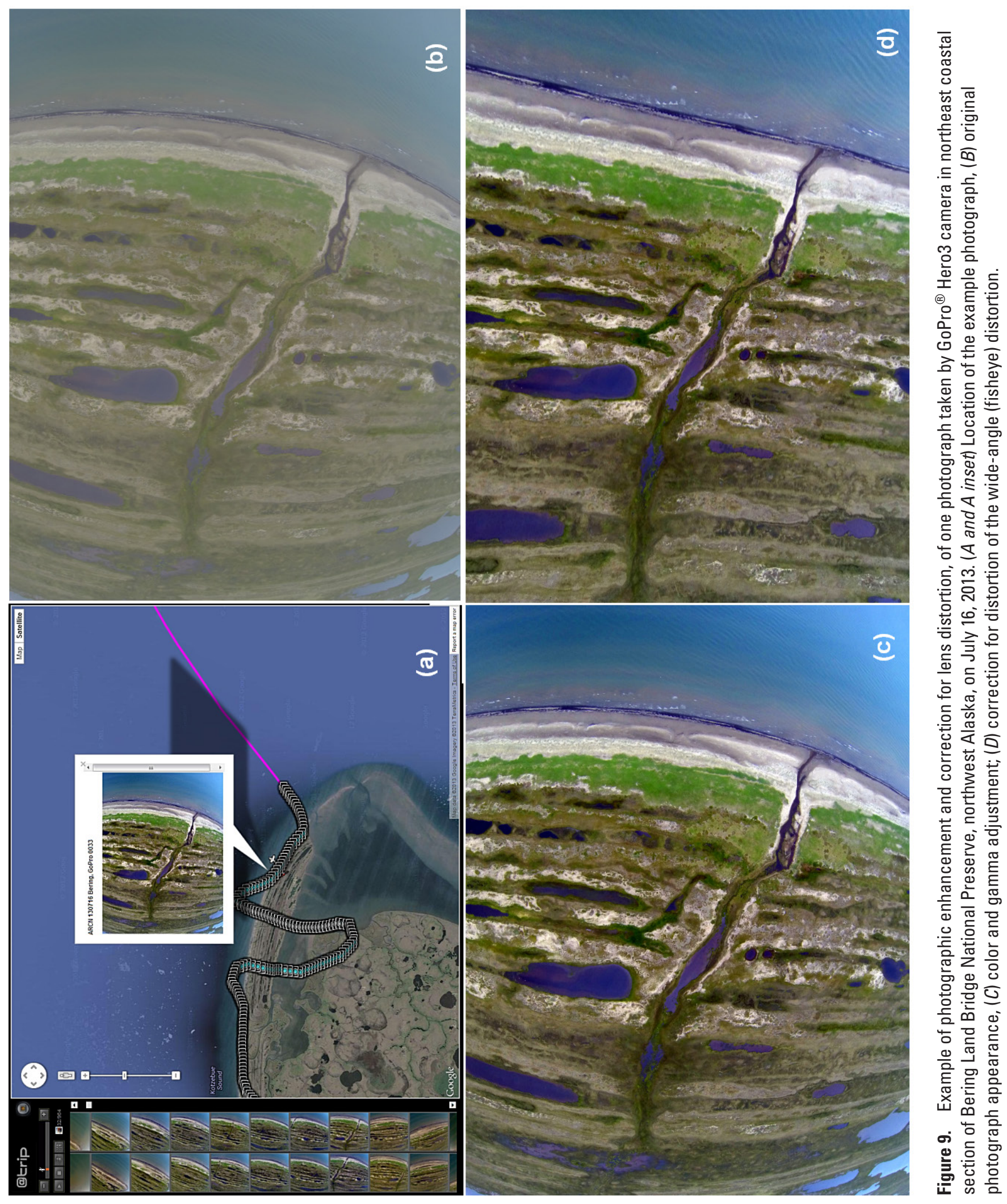


\section{Results}

The 3 days of transect flights through the Arctic Network and Selawik National Wildlife Refuge totaled 17 hours, 45 minutes, of flight time and 2,590 km of linear coverage. A total of 21,161 GPS waypoints were recorded from the i-gotU GT-120 GPS waypoint data logger, and 19,167 still photographs were recorded from the five cameras (table 2). Some example photographs are presented in figures 10 and $\underline{11}$. Given the significant overlap between adjacent photographs (see appendix 1), sequential images can be stitched to produce panoramas (fig. 12, appendix 2), which can provide a far broader view of the landscape with no loss of resolution or rectification. Other manipulations also are possible, such as providing three-dimensional views using sequential, overlapping images.

Numerous digital videos also were produced, including six videos taken with the GoPro ${ }^{\circledR}$ Hero3 camera affixed to the airplane struts or underwing (see figs. $6 \mathrm{~B}$ and $\underline{7 D}$ for video locations). The six GoPro ${ }^{\circledR}$ videos totaled 1 hour, 20 minutes, and 43 seconds of usable coverage and, at a frame rate of $60 \mathrm{fps}$, totaled 290,580 individual extractable frames (table 5). Video frames could be located geographically by comparison with the Drift ${ }^{\circledR}$ camera photographs that were taken simultaneously. Video frame extracts from the enhanced versions of the video files were color- and gamma-adjusted and corrected for lens distortion following procedures and software settings presented in this report to provide highresolution detail (for example, fig. 13). An additional 105 short videos, not geotagged, were taken with the two hand-held Panasonic ${ }^{\circledR}$ Lumix cameras of various landscape scenes, airplane takeoffs and landings, and the ground exploration of an exposed pingo ice core in Bering Land Bridge National Preserve.

Nearly all 44 mapped ecotypes were represented in the photograph transects (fig. 14) with the minor exceptions of Human Modified Barrens, Shadow/Indeterminate, and Snow categories. Each of the three flight routes emphasized a different set of ecotypes, with the most commonly represented ecotypes including coastal water, tussock-shrub and low shrub types, sedge-dryas meadow, and white spruce forest (fig. 14). Although the specific ecotypes and their coverage denoted in the databases for individual photographs may be subject to the accuracy of the original ecotype map (estimated to be 65-80 percent by Jorgenson and others, 2009) at that fine scale, this information is nonetheless useful for determining dominant ecotypes and broader locations along the flight transects where specific ecotypes may be found for future change comparison.

Along all three flight routes, among all 12,395 nadir photographs that were geotagged and intersected with the ecotype map and with the DEM map, the overall average flight altitude AGL was 295 m ( \pm 122 m SD; table 6). Adjusting for elevations during takeoff and landings resulted in an average flight altitude AGL essentially identical to the ideal $300 \mathrm{~m}$ used in time-lapse and areal coverage calculations (appendixes 2 and $\underline{3}$ ), thereby verifying the appropriate use of that value in the calculations.

The GoPro ${ }^{\circledR}$ Hero3 Black Edition camera greatly outperformed the Drift ${ }^{\circledR}$ HD-170 camera for taking betterquality and higher resolution nadir photographs, although both cameras had similar time-lapse capabilities. Mounting a camera on the landing strut structure on the airplane equipped with floats (as was done for the Bering Land Bridge National Preserve flight path) resulted in the floats blocking nearly one-half of each image; thus, an under-wing mount (as was used on other flight routes) is recommended instead for unobstructed views. For hand-held cameras used to take oblique photographs from inside the airplane cockpit, the Canon ${ }^{\circledR}$ Rebel 3Ti digital SLR (single-lens reflex) and the Panasonic ${ }^{\circledR}$ Lumix DMC-FZ200 superzoom cameras provided higher quality images , although the pocket-size Panasonic ${ }^{\circledR}$ Lumix DMC-SZ7 camera also was handy and useful for taking informal short videos of within-cabin, landing, and takeoff sequences.

The GoPro ${ }^{\circledR}$ nadir videos provided some spectacular views as well as numerous individual frames that could be useful for future change comparison studies, particularly from the videos that were corrected for wide-angle lens distortion. Although the individual frames of the videos were not geotagged, the specific scenes could be compared with the static time-lapse photographs of the Drift ${ }^{\circledR}$ camera, which were taken simultaneously, thereby identifying geotag location from the Drift ${ }^{\circledR}$ camera images. It is possible to semi-automate the geotagging of the individual video frames by (1) capturing frames from the videos; (2) identifying from the Drift ${ }^{\circledR}$ camera photographs, the geotagged location and date and time EXIF data for the first frame in the video sequence; (3) applying date and time corrections to subsequent frames by knowing the video frame rate (for example, 60 frames per second) using the EXIF Date Changer ${ }^{\circledR}$ or similar software (table 3); and (4) matching geotag locations of the subsequent video frames to the GPS waypoints taken during the video flight segments. We recommend that any further videos should be taken at the highest possible resolution; resolution is more important than frame rate. For example, the highest video resolution of GoPro ${ }^{\circledR}$ Hero3 Black Edition camera is 4k Cinematic $(4096 \times 2160$ pixels for a 17:9 aspect ratio) at 12 frames per second, which is a fully adequate frame rate. Battery life was the major limitation of the Drift ${ }^{\circledR}$ and GoPro ${ }^{\circledR}$ cameras, which curtailed taking images on a few of the longer flight sequences between landings when we could change batteries.

In conclusion, the set of low-altitude, high-resolution digital photographs gathered in this project is expected to provide a baseline for change comparisons, both future and historical (fig. 15). Results also can complement existing grid-based imaging programs by providing more detailed and continuous images among the grid points. 


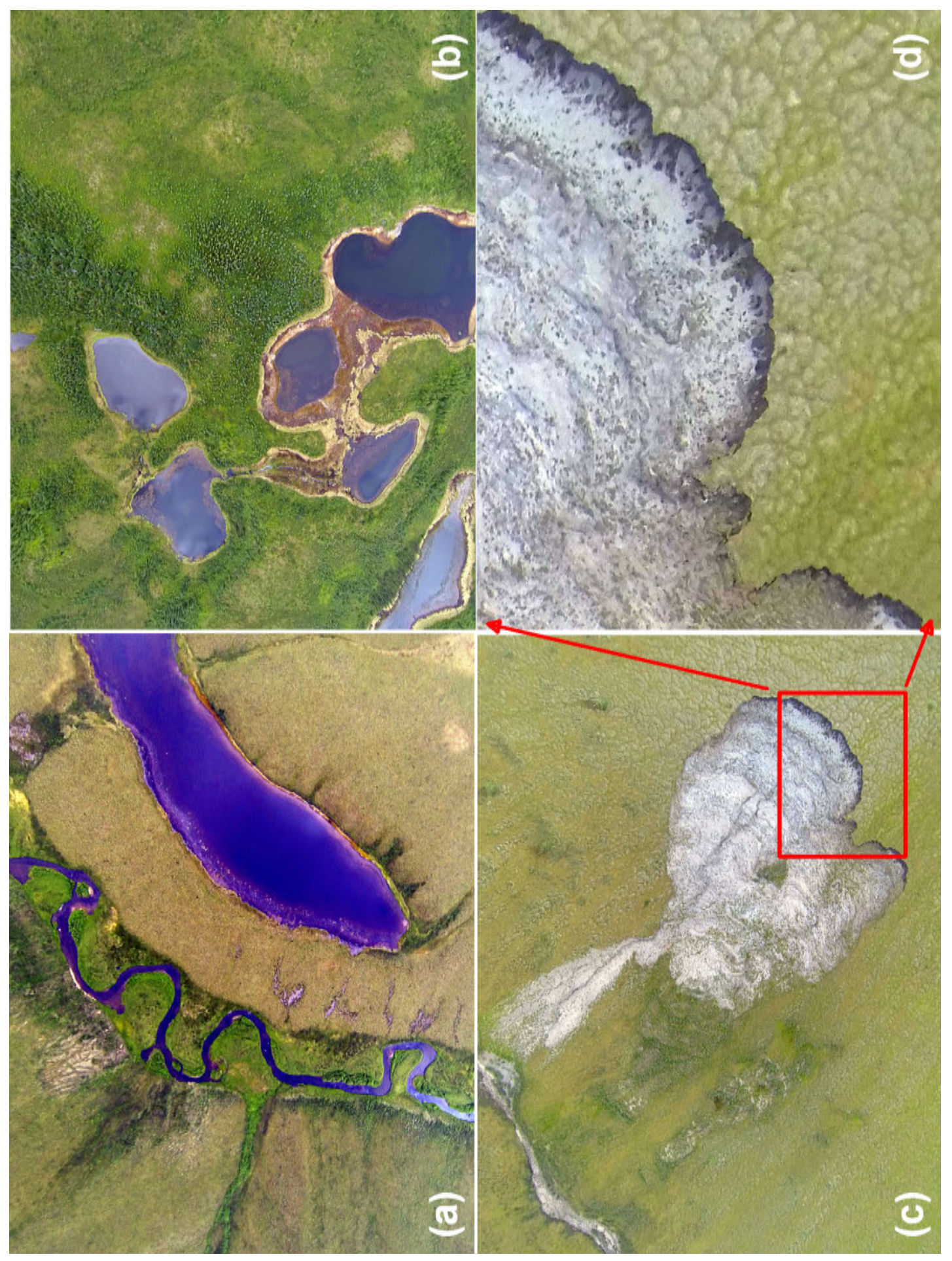

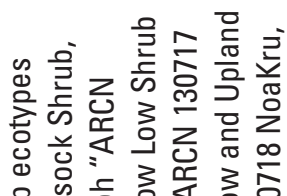

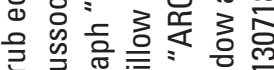

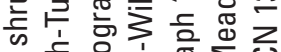

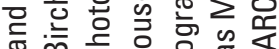

क

은

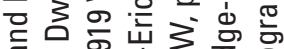

늉

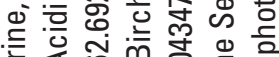

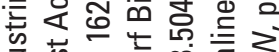

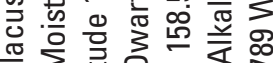

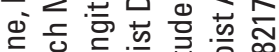

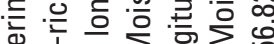

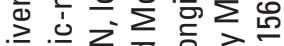

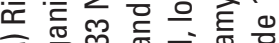

不

匹ं 융

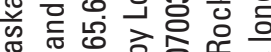

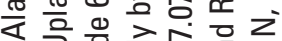

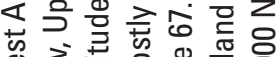

\$

资

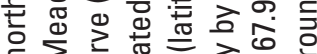

心

을 음

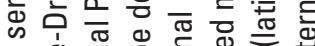

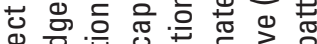

娄

휴 $⿻ 2$ z

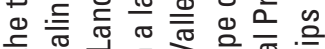

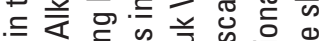

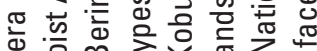

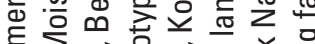

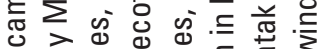

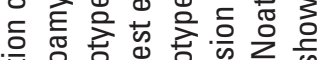

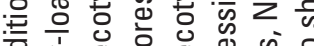

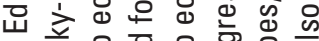

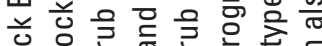

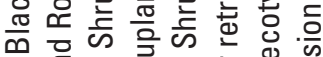

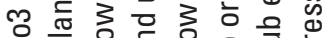

후음을

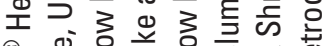

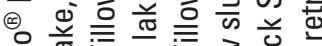

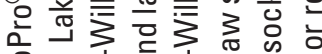

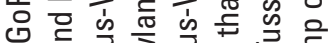

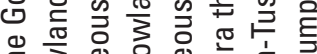

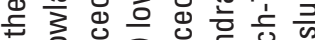

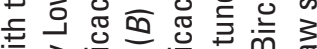

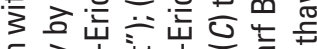

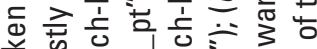

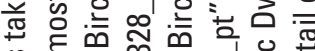

क 든

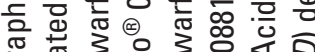

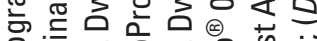

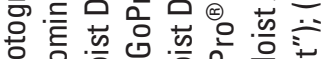

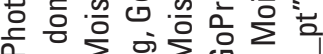

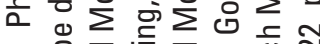

응 든

응

인 응 응

言亲 亭 

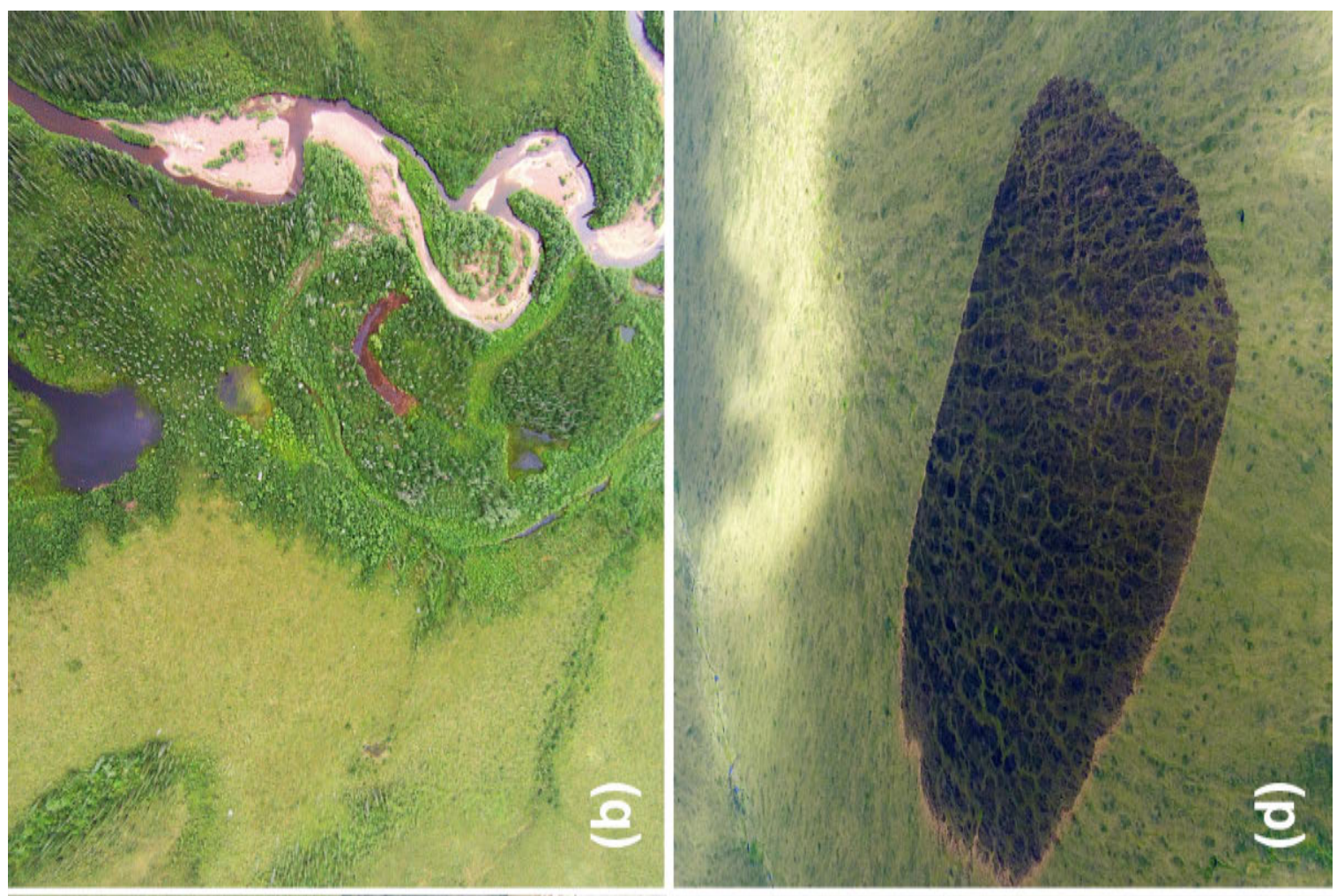

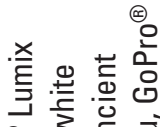

ब.

음

की

结范

듬ㅎำ

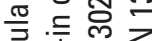

कि

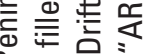

동

3 $\frac{\pi}{\pi}$

음

$\infty$ 음

흐응호음

的里

웡 离志

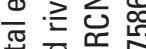

焉 흥

ठำ

立芒苋

离

준

空方文

แ

可令

t范 $\overline{0}$

जण

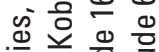

흘 을.

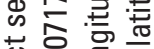

잉 흐

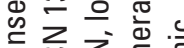

핀

政

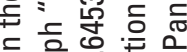

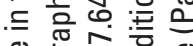

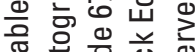

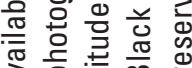

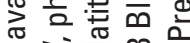

\&

फू के 흐

d

응 엉 응

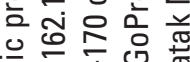

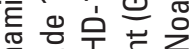

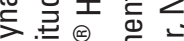

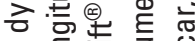

드은

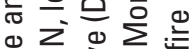

む之记

등 के

은

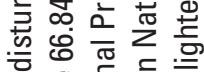

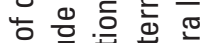

क : D $^{\circ}$ क

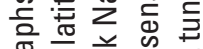

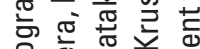

递

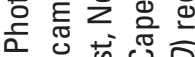

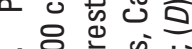

= 윤휴

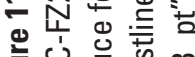

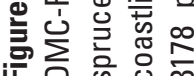



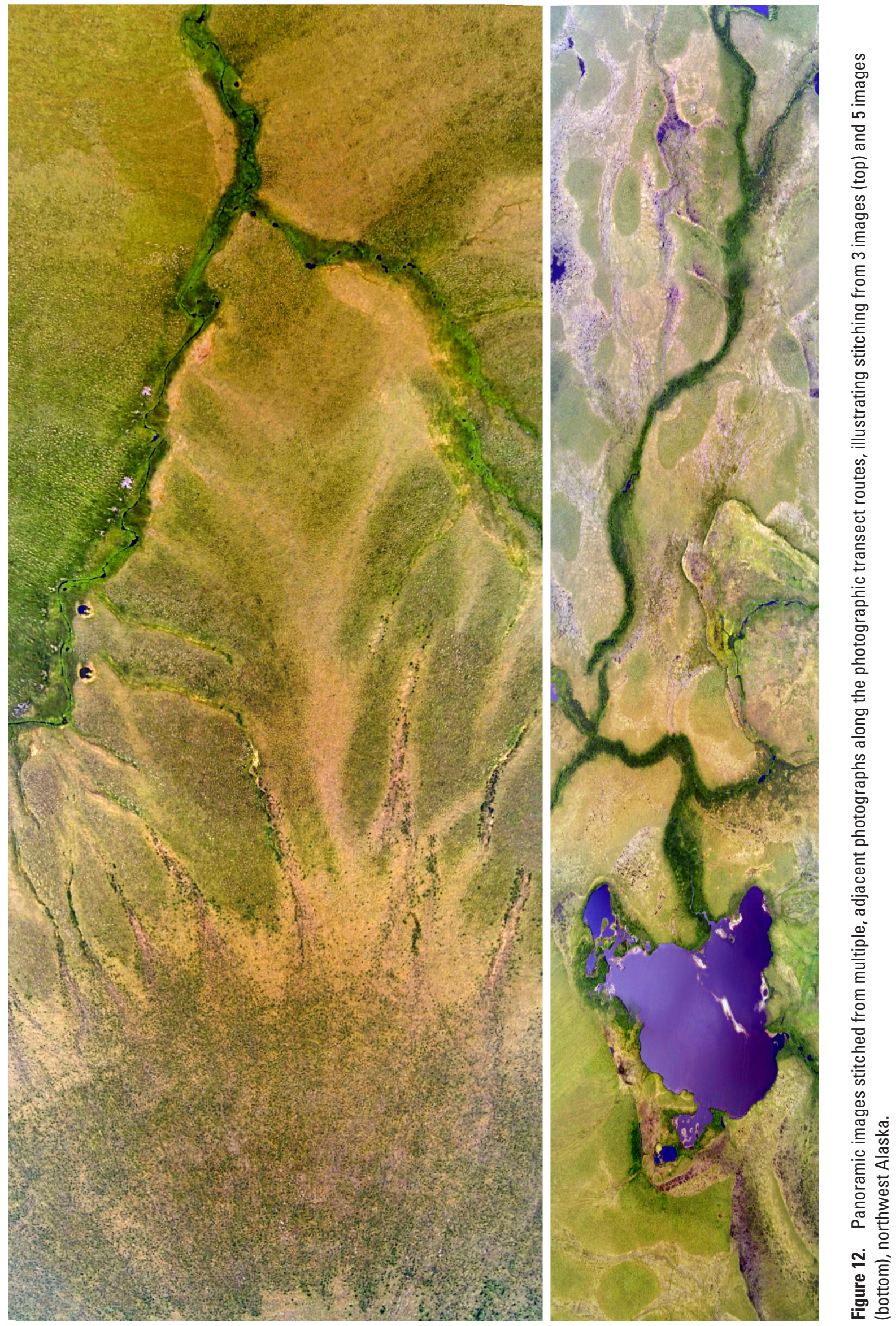

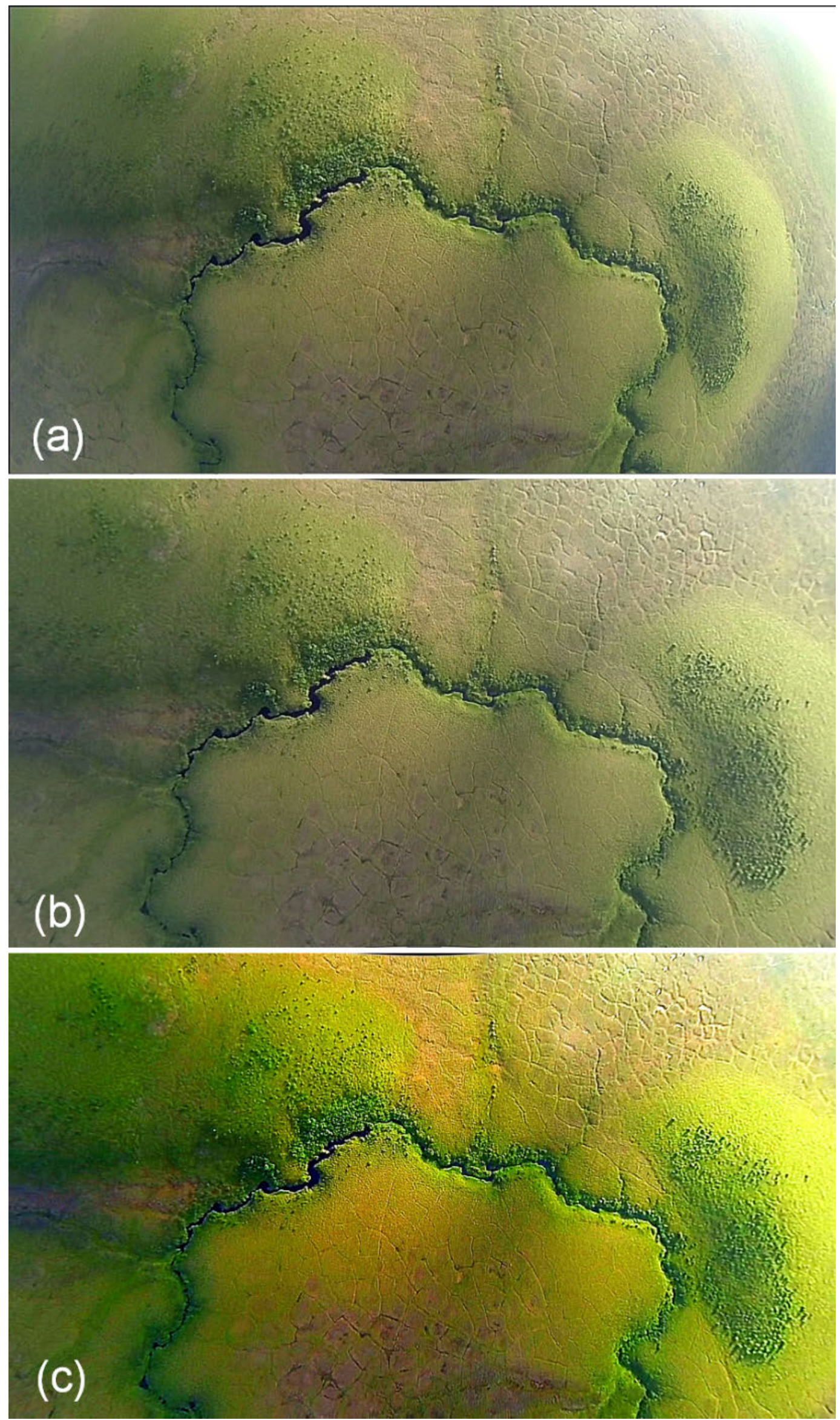

Figure 13. Individual frame-capture from one of the continuous GoPro ${ }^{\circledR}$ Hero3 camera video segments (figs. $6 B, \underline{7 D}$ ), northwestern Alaska. $(A)$ individual frame from one of the videos, $(B)$ correction for lens distortion and cropped to eliminate blank areas, $(C)$ colorenhanced to emphasize patches and boundaries of vegetation and substrate conditions. 

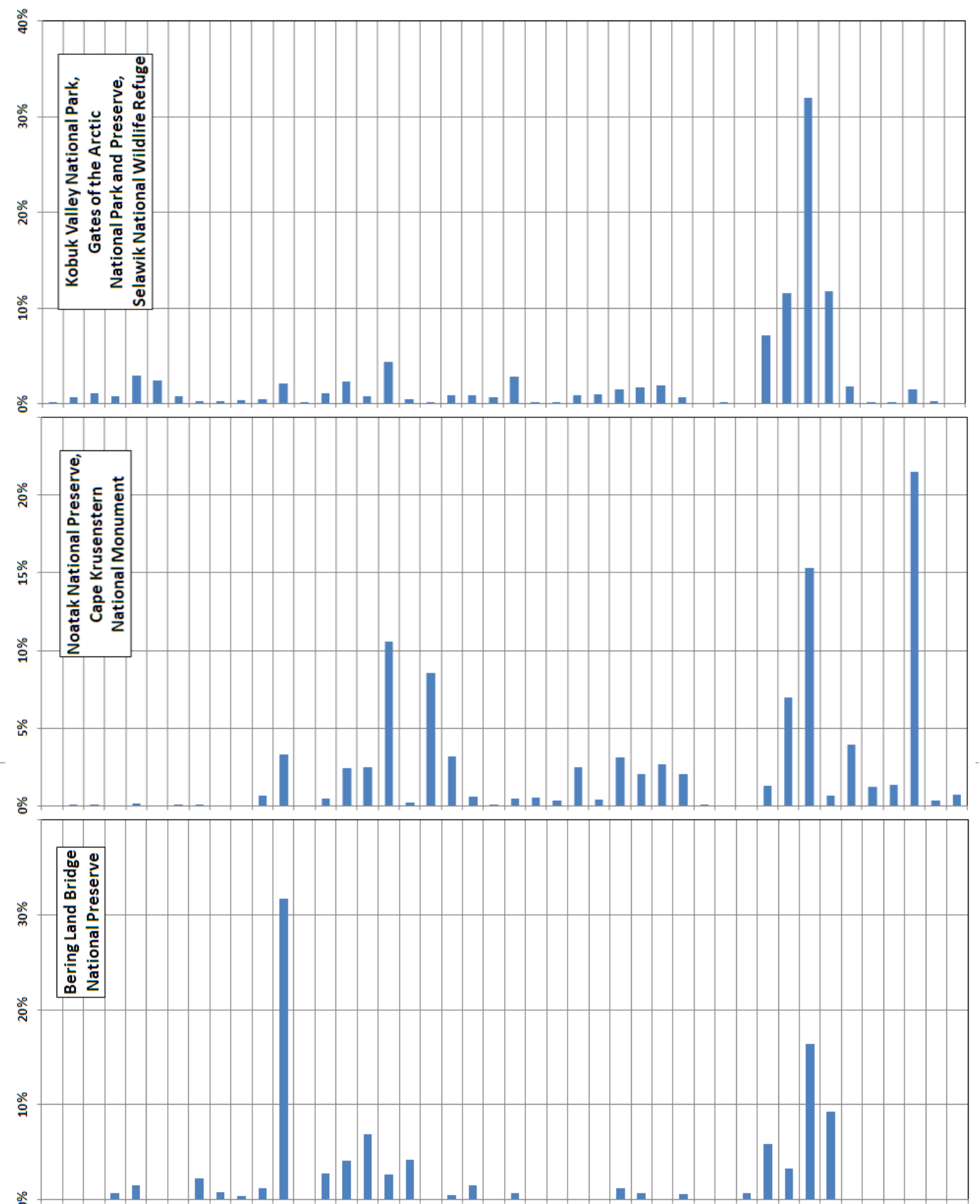

ธำ

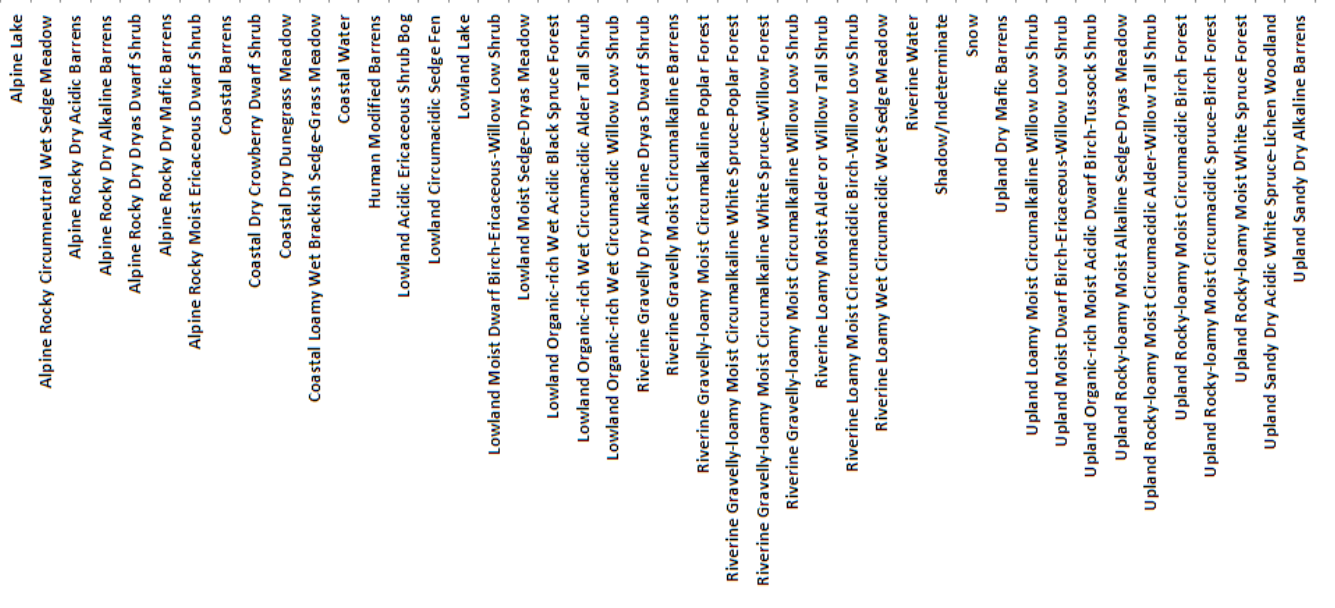

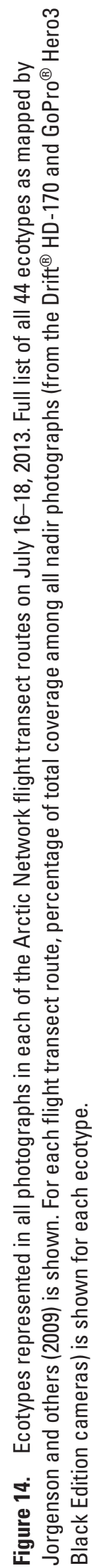


Table 5. Video files of land cover from GoPro ${ }^{\circledR}$ Hero3 camera.

[Video locations during flight paths are shown in figures $6 B$ and $\underline{7 D}$. Time data: Pertain to original videos; processed versions (correction for lens distortion and image-enhanced) include clipping out extraneous material. Number of frames: Number of frames of land cover conditions at video rates of 60 fps, excluding extraneous material (see Comments). Abbreviations: mm, minutes, ss, seconds, fps, frames per second]

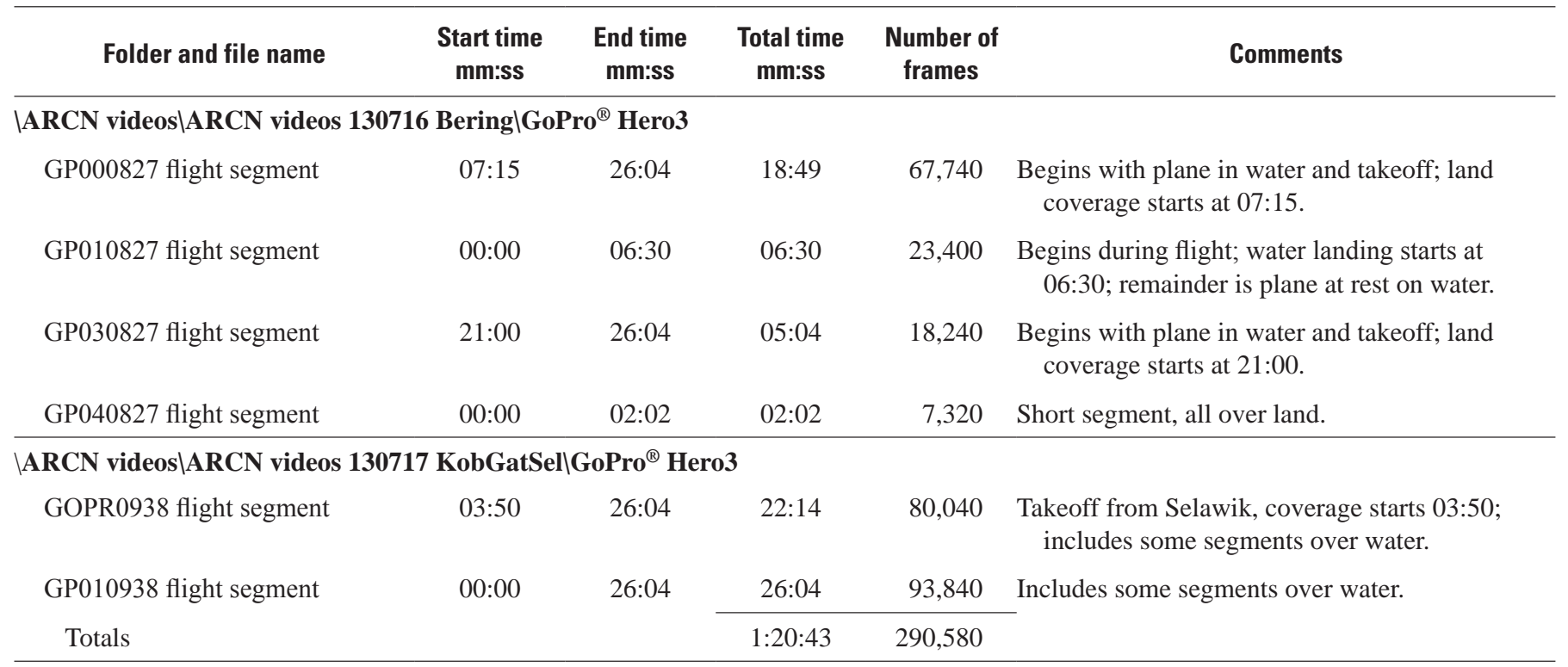

Table 6. Average and standard deviation (SD) of flight altitude of geotagged nadir photographs taken with the Drift ${ }^{\circledR} \mathrm{HD}-170$ and GoPro ${ }^{\circledR}$ Hero3 Black Edition cameras.

[Area: Bering, Bering Land Bridge National Preserve; KobGatSel, Kobuk Valley National Park, Gates of the Arctic National Park and Preserve, and Selawik National Wildlife Refuge; NoaKru, Noatak National Preserve and Cape Krusenstern National Monument. Abbreviations: AGL, above ground level; m, meter]

\begin{tabular}{|c|c|c|c|c|c|c|c|c|}
\hline \multirow[t]{2}{*}{ Area } & \multicolumn{2}{|c|}{$\begin{array}{l}\text { Average flight } \\
\text { altitude AGL } \\
\text { (m) }\end{array}$} & \multicolumn{3}{|c|}{ N (number of photographs) } & \multirow{2}{*}{$\begin{array}{c}\text { Overall average } \\
\text { flight altitude } \\
\text { AGL } \\
\text { (m) } \\
\text { Weighted means }\end{array}$} & \multicolumn{2}{|c|}{$\begin{array}{l}\text { Standard deviation } \\
\text { flight altitude AGL } \\
\text { (m) }\end{array}$} \\
\hline & Drift $^{\circledR}$ & GoPro ${ }^{\circledR}$ & Drift $^{\circledR}$ & GoPro ${ }^{\circledR}$ & Total & & Drift $^{\circledR}$ & GoPro ${ }^{\circledR}$ \\
\hline Bering & 295 & 311 & 1,820 & 632 & 2,452 & 299 & 88 & 106 \\
\hline KobGatSel & 298 & 289 & 2,325 & 2,102 & 4,427 & 294 & 90 & 85 \\
\hline Totals & & & & & 12,395 & 295 & \multicolumn{2}{|c|}{122} \\
\hline
\end{tabular}



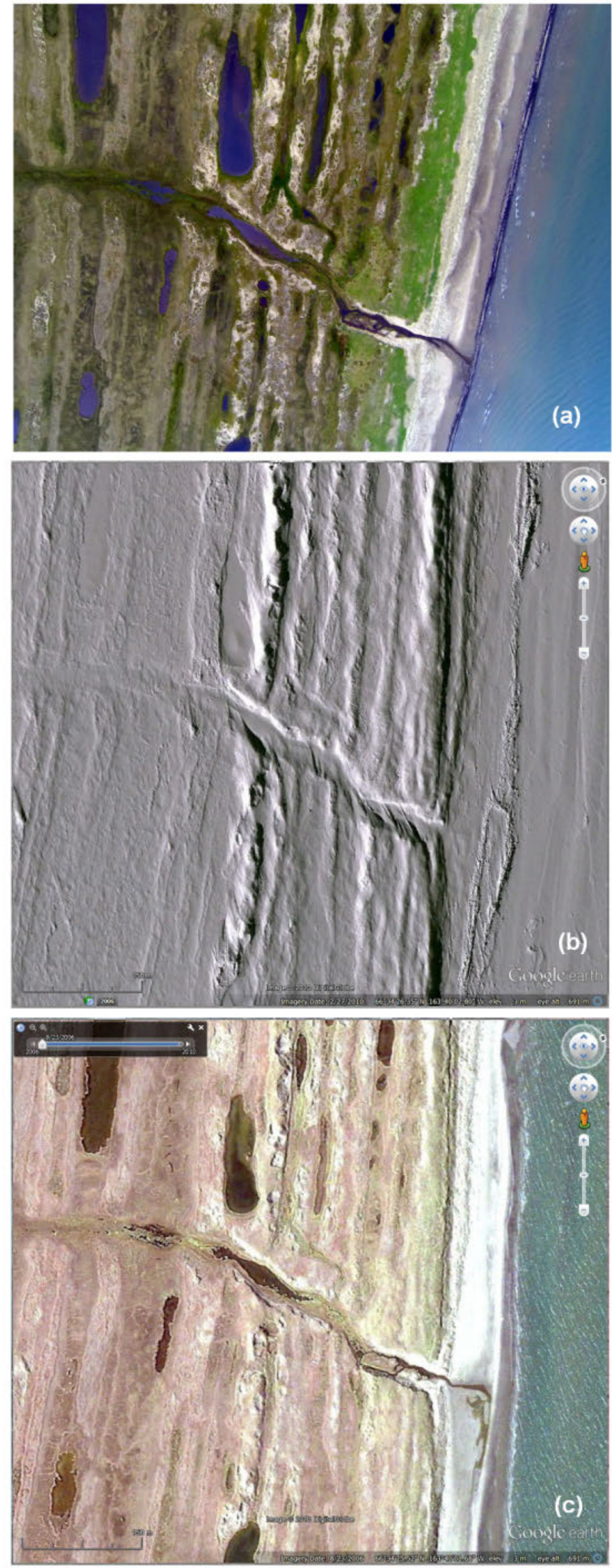

Figure 15. (A) Color- and gamma-adjusted and lens distortion-corrected GoPro ${ }^{\circledR}$ photograph (July 16, 2013; see fig. 9) compared with IKONOS and Worldview images (with 1-meter and 0.5 -meter resolutions, respectively), taken on (B) February 27, 2010, and (C) August 23, 2006 (image source: Google Earth ${ }^{\circledR}$, accessed August 25, 2013). 


\section{Acknowledgments}

This project would not have been possible without the administrative and technical support of Robert Winfree, James Lawler, Frank Hayes, Nick Dougal, and other personnel of the National Park Service (NPS), Fairbanks and Kotzebue, Alaska. The U.S. Geological Survey Alaska Science Center provided financial support to Marcot and Jorgenson through an interagency work agreement and private contract, respectively. We thank James Lawler and NPS for the financial support for the cost of the flights. Flights were conducted by Northwest Aviation, Kotzebue, and we thank pilots Jim Kincaid and Anthony Remboldt. Our appreciation goes to David Swanson for advice and information on his aerial photography projects, to Stacia Backensto for assisting with the use of the Drift ${ }^{\circledR}$ camera, and to John Terenzi for conducting the geographic information system overlays of photograph locations with the study area ecotype map. We thank James Lawler and David Swanson for helpful reviews of the manuscript. All official safety protocols were followed, including coordination with NPS Denali Flight Tracking Center. We thank Dennis Walworth for developing metadocumentation and archiving the files, and Linda Rogers for editing and coordinating this publication.

\section{References Cited}

DeGange, A., Marcot, B.G., Lawler, J., Jorgenson, T., and Winfree, R., 2013, Predicting the effects of climate change on ecosystems and wildlife habitat in northwest AlaskaResults of the WildCast project: Alaska Park Science, v. 12, no. 2, p. 66-73.
Jorgenson, M.T., Roth, J.E., Miller, P.F., Macander, M.J., Duffy, M.S., Wells, A.F, Frost, G.V., and Pullman. E.R., 2009, An ecological land survey and landcover map of the Arctic Network: National Park Service, Natural Resource Technical Report NPS/ARCN/NRTR-2009/270, 307 p.

Necsoiu, M., Dinwiddie, C.L., Walter, G.R., Larsen, A., and Stothoff, S.A., 2013, Multi-temporal image analysis of historical aerial photographs and recent satellite imagery reveals evolution of water body surface area and polygonal terrain morphology in Kobuk Valley National Park: Alaska. Environmental Research Letters, v. 8, no. 2, doi:10.1088/1748-9326/8/2/025007.

Swanson, D.K., 2012a, Mapping of erosion features related to thaw of permafrost in the Noatak National Preserve, Alaska: National Park Service, Natural Resource Data Series NPS/ ARCN/NRDS-2012/248, 21 p.

Swanson, D.K., 2012b, Monitoring of retrogressive thaw slumps in the Arctic Network, 2011-Three-dimensional modeling of landform change.: National Park Service, Natural Resource Data Series NPS/ARCN/NRDS2012/247, Natural Resource Data Series NPS/ARCN/ NRDS-2012/247, 48 p.

Swanson, D.K., 2013, Three decades of landscape change in Alaska's Arctic National Parks-Analysis of aerial photographs, c. 1980-2010: National Park Service, Natural Resource Technical Report NPS/ARCN/NRTR—2013/668, $38 \mathrm{p}$.

Swanson, D.K., and Hill, K. 2010, Monitoring of retrogressive thaw slumps in the Arctic Network, 2010 baseline dataThree-dimensional modeling with small-format aerial photographs: National Park Service, Natural Resource Data Series NPS/ARCN/NRDS—2010/123, 58 p. 


\section{Appendix 1. Calculations of Time-Lapse Interval Needed for Continuous Flight Line Photography}

Following are the calculations made to determine the frequency of the time-lapse interval settings on the Drift ${ }^{\circledR}$ HD-170 and GoPro ${ }^{\circledR}$ Hero3 Black Edition cameras, to ensure overlapping coverage of photographs along the flight transects.

The cameras were secured to the underwing and undercarriage of the Cessna 185 and 206 airplanes, for nadir (direct downward) imaging. Each camera was set to its wide-angle $\left(170^{\circ}\right)$ mode. Later, correcting for lens distortion and cropping of the images reduced the coverage angle to about two-thirds of the original image, resulting in an effective image coverage of about $115^{\circ}$. The airplanes flew at an average altitude a of about $300 \mathrm{~m}$ above ground level (AGL). Thus, effectively, a cross-section triangle was formed as shown in figure A1.

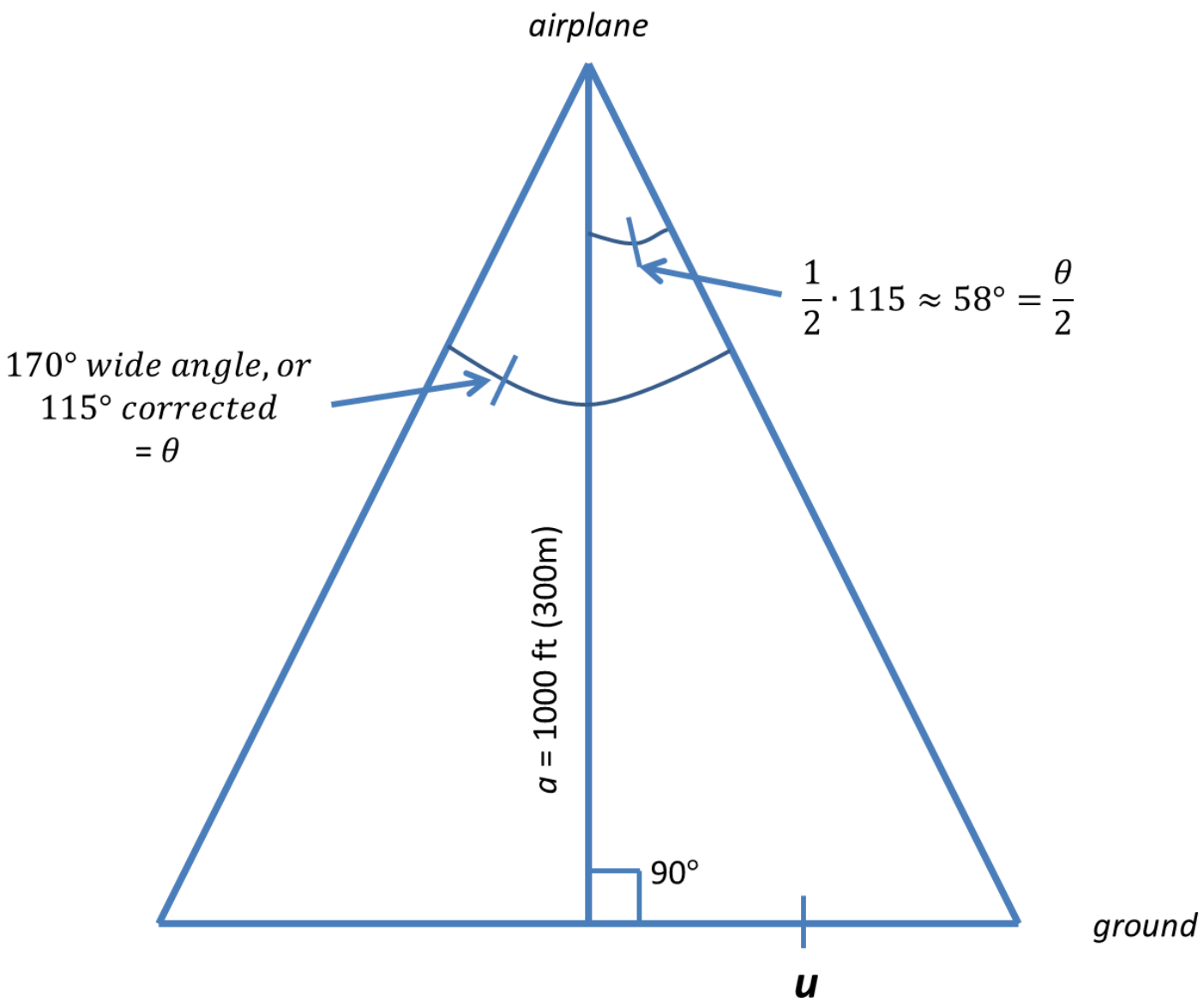

Figure A1. Schematic of the geometry used to calculate ground distance covered during flights with known altitude $a$ and known ground speed. 
In figure A1, the ground distance $u$ represents one-half the span covered by each photograph, and is calculated as:

$$
\tan \left(\frac{\theta}{2}\right)=\frac{u}{a}=u 1000
$$

where, solving for $u$,

$$
u=a \times \tan \left(\frac{\theta}{2}\right)=(1000 \mathrm{ft}) \times \tan \left(58^{\circ}\right)=488 \mathrm{~m}
$$

Next, to determine the time elapsed when the airplane would arrive at the next photograph point with no overlap in ground image, we needed to know the ground speed of the airplane and the distance to be covered, shown as $2 u$ in figure A2.

The airplane flew at an average ground speed of about $190 \mathrm{kph}(104 \mathrm{kt}$ or $54 \mathrm{~m} / \mathrm{s})$. At this rate, covering a distance of $2 u=975 \mathrm{~m}$ would take $(975 \mathrm{~m}) /(54 \mathrm{~m} / \mathrm{s})=18$ seconds.

To account for wide-angle distortion and to enable adjacent photographs to be stitched into panoramic images (see fig. 12), we wanted approximately one-third overlap between adjacent photographs. Therefore, setting the cameras to $(1 / 3)(18$ seconds) resulted in a time-lapse interval of (rounded) one photograph every 6 seconds; the two cameras used for time-lapse photography had settings only at 5-second intervals, so we chose an interval of one photograph every 5 seconds. This meant that for every traverse of $975 \mathrm{~m}$ between exclusive photographic coverage points, there would be a mean of (18 seconds) / (5 seconds/photograph) $=3.6$ photographs, which is generally what was observed in the final product.

The airplane did not fly perfectly at $300 \mathrm{~m}$ altitude AGL and at a $54 \mathrm{~m} / \mathrm{s}$ velocity, but deviations — such as $450 \mathrm{~m}$ altitude AGL and slightly higher velocities_-did not significantly affect the final product. For instance, a flight altitude of $450 \mathrm{~m}$ AGL meant that the distance between exclusive photographic area coverage would be $732 \mathrm{~m}$, so that there would be $(2)(732 \mathrm{~m}) /(54 \mathrm{~m} / \mathrm{s})=27$ seconds elapsed between exclusive photograph points, and at a 5-second photograph time-lapse interval, (27 seconds)/(5 seconds/ photograph $)=5.4$ photographs would be taken, again providing adequate area overlap between adjacent images. We rarely if ever flew below $300 \mathrm{~m}$ altitude AGL for any sustained time period.

\section{airplane flight path $=--+--=-+-\Rightarrow$}

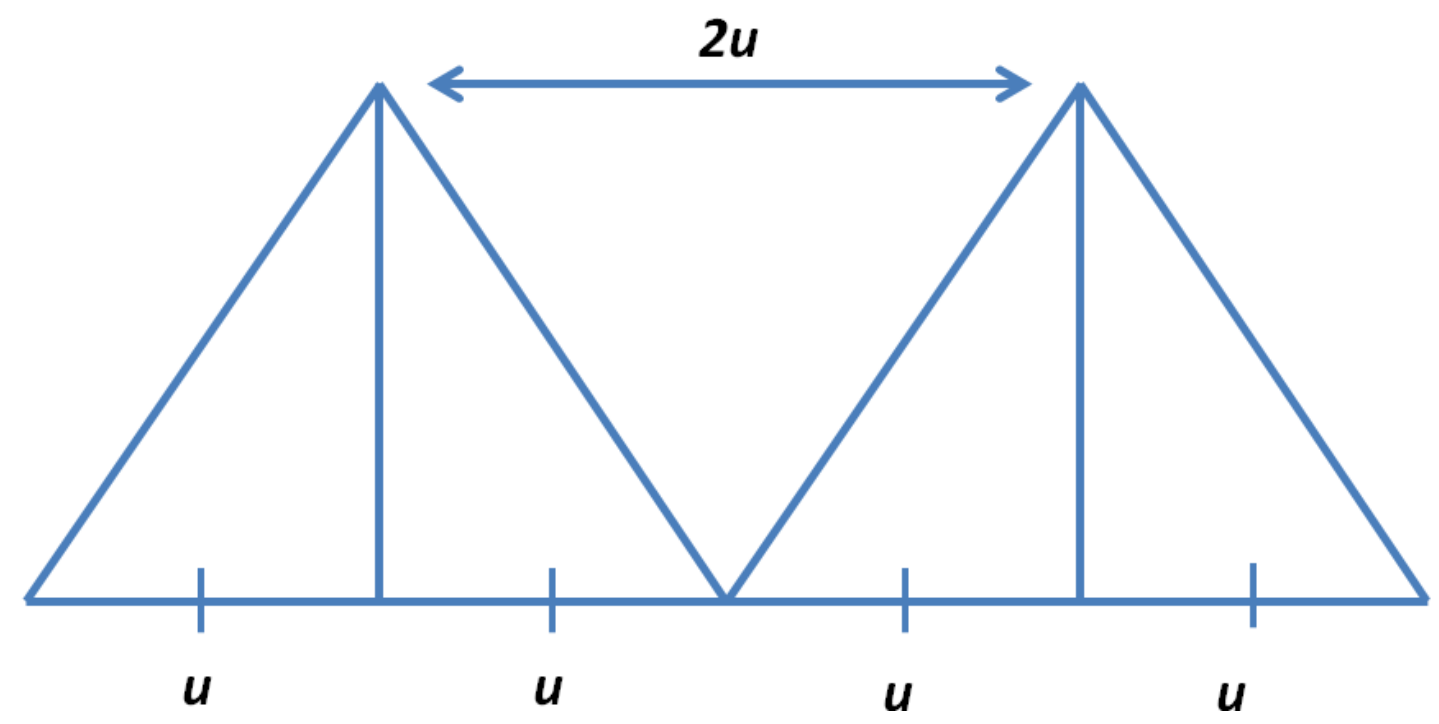

Figure A2. Schematic of the geometry used to calculate distance $2 u$ and the timing between successive time-lapse photographs. 


\section{Appendix 2. Details of Photograph Processing}

The following eight steps were followed in processing the photographs from this project. Methods are presented here in detail—including problems encountered and solutions devised - to potentially aid future photographers engaged in similar project work. See tables 1 and $\underline{3}$ for information on hardware and software used.

\section{STEP 1: Downloading and sorting photographs from cameras.}

Photographs were downloaded from each camera and each day's flight and were stored in separate subdirectories (folders) on a computer. Photographs (.jpg files) and videos (.mp4 files, later converted into .wmv files) were sorted into different folders.

The cameras automatically created new folders on the SD cards when the cameras were shut off and turned back on (upon landing or takeoff), when batteries were replaced, and when 999 photographs were taken on a camera for any continuous time-lapse series. This resulted in the cameras automatically creating files with the same names (which were placed automatically in different subdirectories on the cameras' memory cards).

Redundant photographs in each photograph set were deleted, such as time-lapse images taken when the airplane was stationary, long sequences taken over water, and other photographs with no usable content.

Note that photographs from the Drift ${ }^{\circledR}$ camera from the July 16, 2013 flight tracks in Bering Land Bridge National Preserve are only partial images. The Drift camera could be secured on that airplane only to the struts of the external step where the nadir orientation of the lens was partially obscured by one of the airplane floats.

Resulting photograph file directory name: WildCast ARCN photo study 01 ORIGINAL

\section{STEP 2: Correcting EXIF (exchangeable image file format) date and time stamps to fix erroneous date-time stamps.}

The internal date and time information on individual photograph runs (flight legs) became reset in the Drift and GoPro ${ }^{\circledR}$ cameras to an incorrect default value when the cameras were switched off and back on or when batteries were replaced (that is, contrary to expectations, the cameras did not retain the correct date and time settings). Having the exact, precise date and time for each photograph is critical to correctly geotagging each image. However, photographs in each "reset" series retained their relative difference in date and time among each other, so what was needed was to determine the correct date and time for any one photograph of the series and then apply that same relative date and time correction to all photographs of that series, and to repeat the process for each photograph series. This entailed going through the photograph folders from all cameras, flight dates, and subfolders thereof, and locating one or several photographs (for accuracy spot checks) and comparing them to the exact date and time (yy:dd:hh:mm:ss) and the exact location (latitude, longitude) when and where they were taken.

This was determined by reading the .gpx GPS waypoint data into@trip PC ${ }^{\circledR}$ software that shows each GPS track and waypoint superimposed over zoomable satellite imagery. When a uniquely shaped tundra lake, a town, or other clearly identifiable landmark centered on a photograph was identified on the Landsat imagery, that same exact spot then was located along the GPS track, at which that GPS data point's date and time were identified. Next, a time calculator was used to determine the difference from the photograph's (incorrect) EXIF date and time for that point. This resulted in determining the specific date and time increment or decrement needed to adjust the EXIF data of the photograph to perfectly match the (correct) GPS data. This was done for each set of photographs from each combination of camera, flight date, and photograph track, and the corrections for each photograph track were verified with spot checks of the alignment of other photographs not used to determine the correction for that track.

It was important to amend the photograph files' EXIF data, not the files' "Windows" date and time such as appears in Microsoft ${ }^{\circledR}$ Windows Explorer in the Windows-based computer used. To amend the EXIF data by incrementing or decrementing a specified yyyy:dd:hh:mm:ss, the software EXIF Date Changer ${ }^{\circledR}$ was used in which yyyy was reset to a specified year if needed (using the software function "set date/time to"), or the time stamp was adjusted by specific decrements or increments (using the function "adjust time by"), at the same time also resetting the Windows file created date and time to the corrected (actual) taken date and time.

Resulting photograph file directory name: WildCast ARCN photo study 02 TIME DATE ADJUSTED

\section{STEP 3: Color adjustment, image enhancement.}

Each photograph was adjusted for color and gamma settings to help bring out details, by using the software Irfanview ${ }^{\circledR}$ in batch mode, specifying the "auto adjust color" option and "save with original .jpg quality" option.

GoPro camera videos were adjusted by using GoPro Studio for orientation (flight direction at top of image) and image enhancement (Protune color and gamma), and stored in file directories named "GoPro Hero3 CORRECTED, ENHANCED."

Resulting photograph file directory name: WildCast ARCN photo study 03 IMAGE ENHANCED 


\section{STEP 4: Renaming photograph files.}

All photograph files then were globally renamed to provide mnemonic names denoting the overall study area, flight date, specific study area units flown, and camera used.

The files were renamed using these name templates:

ARCN 130716 Bering, Drift xxxx

ARCN 130716 Bering, GoPro xxxx

ARCN 130716 Bering, Lumix xxxx

ARCN 130716 Bering, LumixSZ7 xxxx

ARCN 130716 Bering, Canon xxxx

ARCN 130717 KobGatSel, Drift xxxx

ARCN 130717 KobGatSel, GoPro xxxx

ARCN 130717 KobGatSel, Lumix xxxx

ARCN 130717 KobGatSel, LumixSZ7 xxxx

ARCN 130717 KobGatSel, Canon xxxx

ARCN 130718 NoaKru, Drift xxxx

ARCN 130718 NoaKru, GoPro xxxx

ARCN 130718 NoaKru, Lumix xxxx

ARCN 130718 NoaKru, LumixSZ7 xxxx

ARCN 130718 NoaKru, Canon xxxx

where:

\begin{tabular}{|c|c|}
\hline ARCN & National Park Service’s Arctic Network \\
\hline \multicolumn{2}{|r|}{ Date } \\
\hline $13071 x$ & yymmdd flight date \\
\hline \multicolumn{2}{|r|}{ Location } \\
\hline Bering & Bering Land Bridge National Preserve \\
\hline Kob & Kobuk Valley National Park \\
\hline Gat & Gates of the Arctic National Park and Preserve \\
\hline Sel & Selawik National Wildlife Refuge \\
\hline Noa & Noatak National Preserve \\
\hline Kru & Cape Krusenstern National Monument \\
\hline \multicolumn{2}{|r|}{ Cameras used } \\
\hline Drift & Drift HD-170 \\
\hline GoPro ${ }^{\circledR}$ & GoPro ${ }^{\circledR}$ Hero3 Black Edition \\
\hline Lumix & Panasonic Lumix DMC-FZ200 \\
\hline LumixSZ7 & Panasonic Lumix DMC-SZ7 \\
\hline Canon & Canon Rebel 3Ti \\
\hline
\end{tabular}

Resulting photograph file directory name: WildCast

ARCN photo study 04 FILES RENAMED
STEP 5: Geotagging all photographs.

Each photograph then was geotagged to the GPS flight paths using the @trip PC software that matched each photograph EXIF date and time stamp to that of the GPS data to determine the exact location of the photograph. This resulted in adding decimal latitude and longitude stamps to the EXIF data of each photograph.

Resulting photograph file directory name: WildCast ARCN photo study 05 GEOTAGGED

\section{STEP 6: Lens distortion correction and cropping of Drift and GoPro photographs.}

Photographs from the GoPro ${ }^{\circledR}$ and Drift cameras then were corrected for lens distortion, as those two cameras produced fixed wide-angle images with edge distortion. The program PTLens ${ }^{\circledR}$ was used for this function. Program parameters needed in PTLens to correct for lens distortion were determined by (1) communication with Tom Niemann, author of PTLens, who suggested program settings appropriate for correcting the wide-angle distortion of the GoPro ${ }^{\circledR}$ camera images; (2) inspecting the (commensurate) settings posted by Paul Illsley at his GoPro ${ }^{\circledR}$ Hero2 Aerial Imaging and Mapping Project web site (http://www.paulillsley.com/GoPro/ Airphoto/), in which he used PTLens to correct for the wideangle GoPro ${ }^{\circledR}$ aerial images taken from a small airplane in a fashion quite similar to this project's setup; and (3) testing the settings with images containing known straight landscape lines such as roadways. The PTLens values used to correct the ARCN aerial photograph nadir images were: distortion type $=$ fisheye; fisheye distortion setting $=120$; and crop $=$ 20. Also specified were JPEG Quality $=100$ under Options to minimize information loss as each corrected image was saved. Note, too, that each image was cropped to exclude the margins containing black parabolic areas that resulted from the image rectification. This cropping excluded from each photograph only a small part containing the most distorted corner images. Note that this procedure to correct the images was essentially a first approximation, as it did not correct for oblique views caused by tilt of the airplane.

The program PTLens creates new files with a common, user-specified file name suffix (default is *_pt). To then delete (or move) the original files, the utility program xplorer $2^{\circledR}$ (a replacement for Microsoft Windows Explorer) was used. In xplorer2, “_pt.jpg” was entered in the "Select” box, which then highlighted all new (corrected for lens distortion) files with that filename suffix, and then Mark / Invert was selected so that all files without_pt were highlighted and then could be easily deleted or moved in batch mode.

Resulting photograph file directory name: WildCast ARCN photo study 06 CORRECTED 


\section{STEP 7: Extraction of EXIF data.}

All EXIF data in the photographs then were extracted into .csv files by using the program BR's EXIFextracter ${ }^{\circledR}$ and were converted into.xlsx spreadsheet file format by using Microsoft Excel 2010. Separate .xlsx spreadsheet files were created for each combination of flight date, route, and camera. Resulting files (names were coded, as described further in Step 4) were named:

ARCN 130716 Bering, Drift EXIF data.xlsx ARCN 130716 Bering, GoPro EXIF data.xlsx ARCN 130716 Bering, Lumix EXIF data.xlsx ARCN 130716 Bering, LumixSZ7 EXIF data.xlsx ARCN 130716 Bering, Canon EXIF data.xlsx ARCN 130717 KobGatSel, Drift EXIF data.xlsx ARCN 130717 KobGatSel, GoPro EXIF data.xlsx ARCN 130717 KobGatSel, Lumix EXIF data.xlsx ARCN 130717 KobGatSel, LumixSZ7 EXIF data.xlsx ARCN 130717 KobGatSel, Canon EXIF data.xlsx ARCN 130718 NoaKru, Drift EXIF data.xlsx ARCN 130718 NoaKru, GoPro EXIF data.xlsx ARCN 130718 NoaKru, Lumix EXIF data.xlsx ARCN 130718 NoaKru, LumixSZ7 EXIF data.xlsx ARCN 130718 NoaKru, Canon EXIF data.xlsx

\section{STEP 8: Overlay with ecotype map.}

The set of ecotypes captured in each nadir photograph then were identified and recorded in the EXIF spreadsheet files by overlaying in the $\operatorname{ArcMap}^{\circledR}$ geographic information system (GIS; table 3) the latitude and longitude EXIF data of each photograph onto the ecotype map of the study area. The resulting files were named as in Step 7 and appended with "w ecotypes," with ecotype names included as new data fields for each photograph and data entered as the number of ecotype map pixels represented in each photograph. Details of the GIS overlay procedure are explained further in appendix 3.

\section{Additional Photograph Manipulations}

We provided examples of stitching together overlapping images to create contiguous panoramic images (see fig. 12). Many computer programs are available for stitching digital photographs, including Irfanview; we used ArcSoft ${ }^{\circledR}$

Panorama Maker version 3 for our examples in this report (see table 3). 


\section{Appendix 3. Analysis of Ecotype Coverage in Photographs}

Ecotypes (land and water cover types) that were present in the nadir photographs (taken with the Drift HD-170 and GoPro ${ }^{\circledR}$ Hero3 Black Edition cameras; table 1) were determined in GIS (ArcMap 10; table 3) by intersecting the geotagged locations of each photograph with the map of ecotypes developed by Jorgenson and others (2009) for the Arctic Network (ARCN) study area.

Nadir photographs were taken at $2592 \times 1944$ photographic pixels (5 megapixels) with the Drift camera and $4000 \times 3000$ photographic pixels (12 megapixels) with the GoPro ${ }^{\circledR}$ camera; thus, with an aspect ratio of $4: 3$ or 1.33:1. Using the flight geometry applied to determine photograph time-lapse intervals (appendix 1), at a mean flight altitude of $300 \mathrm{~m}$ above ground level and an effective lens angle of approximately $115^{\circ}$, each photograph in its corrected and cropped format covered a rectangular area with a width of

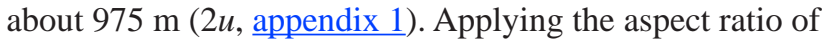
each photograph, the coverage length of each photograph was $975 \mathrm{~m} / 1.33=732 \mathrm{~m}$. Thus, the area covered by each corrected photograph was $975 \mathrm{~m} \times 732 \mathrm{~m}=71$ hectares (ha).

Ecotypes were mapped by Jorgenson and others (2009) at a pixel size of $28.5 \mathrm{~m} \times 28.5 \mathrm{~m}\left(812.25 \mathrm{~m}^{2}\right)$. Centering the geotagged location (latitude an $\mathrm{d}$ longitude) of each photograph on the ecotype map, a GIS window of $25 \times 25$ map pixels was a tractable means of approximating most of the area covered by each corrected and cropped photograph (J. Terenzi, written commun., February 24, 2014). The resulting GIS window at each photograph location, therefore, covered 51 ha on the ecotype map (= $[25 \times 25$ pixels $] \times\left[812.25 \mathrm{~m}^{2} /\right.$ pixel $\left.]\right)$. 


\section{Appendix 4. Metadata Documentation of Arctic Network Photograph Database Files}

Following are descriptions of the data fields found within the Arctic Network (ARCN) photograph database and spreadsheet files in the computer folder named "ARCN photo GPS (EXIF) data spreadsheets.” The individual ARCN digital photograph database files are named following the convention noted in appendix 2.

The database files are saved as both comma-separated value text (ASCII) format (.csv) and Microsoft ${ }^{\circledR}$ Excel 2010 format (.xlsx).

Each record in the ARCN photograph database files pertains to a specific digital photograph and generally includes information on photograph file name, camera type and settings, and geolocation of the photograph. All this information came directly from each photograph file's exchangeable image file format (EXIF) data (corrected for time and location, as described in appendix 2).
Three sets of ARCN photograph database files were developed for this project, in these computer folder names: (1) "Nadir Photographs All," which provides the abovementioned EXIF data fields for all photographs taken vertically downward, with the Drift ${ }^{\circledR} \mathrm{HD}-170$ and GoPro ${ }^{\circledR}$ Hero3 Black Edition cameras; (2) "Nadir Photographs With Ecotypes," which is a subset of the "Nadir Photographs All" set that was within the boundaries of the map of ecotypes (land and water cover types) in the ARCN study area (see text for explanation); and (3) "Oblique Photographs," which provides the EXIF data fields for photographs, taken by hand during the photographic transect flights, with the Panasonic ${ }^{\circledR}$ Lumix DMC-FZ200, Panasonic Lumix DMC-SZ7, and Canon ${ }^{\circledR}$ Rebel 3 Ti cameras. Database files pertaining to set (2) also include data on flight altitude and on extent of each ecotype category present within each photograph (see text and appendix 3); these additional data fields are noted in the following table.

\begin{tabular}{|c|c|}
\hline Data field & Description \\
\hline File name & Name of the photographic image computer file (.jpg) \\
\hline Camera make & Make of the camera used to take the photograph \\
\hline Camera model & Model of the camera used to take the photograph \\
\hline Height $\mathrm{x}$ width & Size of the digital image in pixels \\
\hline Aperture (F-number) & F-stop of the photograph \\
\hline ISO & $\begin{array}{l}\text { Sensitivity ("film speed") setting of the photograph (ISO = International Organization of } \\
\text { Standardization) }\end{array}$ \\
\hline Flash used? & Whether camera flash was used for the photograph (all "no") \\
\hline Focal length & Focal length (focus distance to object) of the photograph \\
\hline Flight altitude ASL & Altitude of the airplane above sea level (ASL) when the photograph was taken, in meters \\
\hline DEM elevation & $\begin{array}{l}\text { Ground-level elevation at the center of the photograph, as taken from a digital elevation model } \\
\text { (DEM) map in the ArcMap geographic information system, in feet }\end{array}$ \\
\hline Flight altitude AGL & $\begin{array}{l}\text { Altitude of the airplane above ground level (AGL) at the center of the photograph, in feet; } \\
\text { calculated by: [Flight altitude ASAL in meters] - ([DEM elevation in feet] / [3.281 feet/meter]) }\end{array}$ \\
\hline
\end{tabular}


The following fields pertain to the 44 mapped ecotypes; data in each field pertain to number of map pixels $\left(1 \mathrm{pixel}=28.5 \times 28.5 \mathrm{~m}=812.25 \mathrm{~m}^{2}\right)$ of each ecotype that appeared in a GIS window 51 hectares in area centered on each photograph (appendix 3).

Alpine Lake

Alpine Rocky Circumneutral Wet Sedge Meadow

Alpine Rocky Dry Acidic Barrens

Alpine Rocky Dry Alkaline Barrens

Alpine Rocky Dry Dryas Dwarf Shrub

Alpine Rocky Dry Mafic Barrens

Alpine Rocky Moist Ericaceous Dwarf Shrub

Coastal Barrens

Coastal Dry Crowberry Dwarf Shrub

Coastal Dry Dunegrass Meadow

Coastal Loamy Wet Brackish Sedge-Grass Meadow

Coastal Water

Human Modified Barrens

Lowland Acidic Ericaceous Shrub Bog

Lowland Circumacidic Sedge Fen

Lowland Lake

Lowland Moist Dwarf Birch-Ericaceous-Willow Low Shrub

Lowland Moist Sedge-Dryas Meadow

Lowland Organic-rich Wet Acidic Black Spruce Forest

Lowland Organic-rich Wet Circumacidic Alder Tall Shrub

Lowland Organic-rich Wet Circumacidic Willow Low Shrub

Riverine Gravelly Dry Alkaline Dryas Dwarf Shrub
Riverine Gravelly Moist Circumalkaline Barrens

Riverine Gravelly-loamy Moist Circumalkaline Poplar Forest

Riverine Gravelly-loamy Moist Circumalkaline White Spruce-Poplar Forest

Riverine Gravelly-loamy Moist Circumalkaline White Spruce-Willow Forest

Riverine Gravelly-loamy Moist Circumalkaline Willow Low Shrub Riverine Loamy Moist Alder or Willow Tall Shrub

Riverine Loamy Moist Circumacidic Birch-Willow Low Shrub

Riverine Loamy Wet Circumacidic Wet Sedge Meadow

Riverine Water

Shadow/Indeterminate

Snow

Upland Dry Mafic Barrens

Upland Loamy Moist Circumalkaline Willow Low Shrub

Upland Moist Dwarf Birch-Ericaceous-Willow Low Shrub

Upland Organic-rich Moist Acidic Dwarf Birch-Tussock Shrub

Upland Rocky-loamy Moist Alkaline Sedge-Dryas Meadow

Upland Rocky-loamy Moist Circumacidic Alder-Willow Tall Shrub

Upland Rocky-loamy Moist Circumacidic Birch Forest

Upland Rocky-loamy Moist Circumacidic Spruce-Birch Forest

Upland Rocky-loamy Moist White Spruce Forest

Upland Sandy Dry Acidic White Spruce-Lichen Woodland

Upland Sandy Dry Alkaline Barrens 


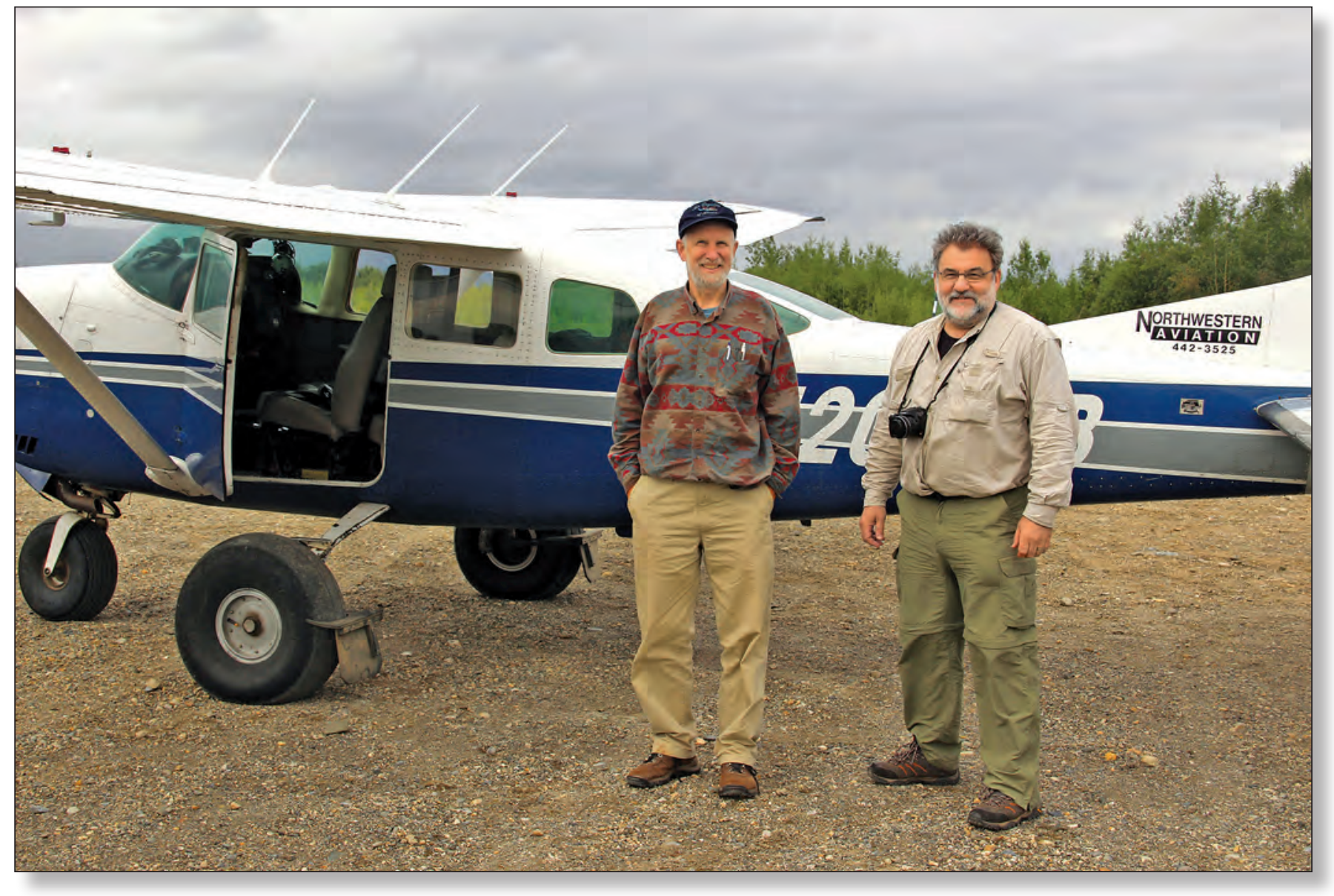

Authors M. Torre Jorgenson (left) and Bruce G. Marcot (right) in Gate of the Arctic National Park and Preserve (photograph taken by pilot Anthony Remboldt).

Publishing support provided by the U.S. Geological Survey Publishing Network, Tacoma Publishing Service Center

For more information concerning the research in this report, contact the Director, Alaska Science Center

U.S. Geological Survey

4210 University $\mathrm{Dr}$

Anchorage, Alaska 99508-4560

http://alaska.usgs.gov 
